\title{
Dissecting the Signaling Mechanisms Underlying Recognition and Preference of Food Odors
}

\author{
Gareth Harris, ${ }^{1}$ Yu Shen, ${ }^{1}$ Heonick Ha, ${ }^{1}$ Alessandra Donato, ${ }^{2}$ Samuel Wallis, ${ }^{1}$ Xiaodong Zhang, ${ }^{1}$ and Yun Zhang ${ }^{1}$ \\ ${ }^{1}$ Department of Organismic and Evolutionary Biology, Center for Brain Science, Harvard University, Cambridge, Massachusetts 02138, and ${ }^{2}$ Institute of \\ Genetics and Biophysics of the National Research Council, 80131 Naples, Italy
}

\begin{abstract}
Food is critical for survival. Many animals, including the nematode Caenorhabditis elegans, use sensorimotor systems to detect and locate preferred food sources. However, the signaling mechanisms underlying food-choice behaviors are poorly understood. Here, we characterize the molecular signaling that regulates recognition and preference between different food odors in $C$. elegans. We show that the major olfactory sensory neurons, AWB and AWC, play essential roles in this behavior. A canonical G $\alpha$-protein, together with guanylate cyclases and cGMP-gated channels, is needed for the recognition of food odors. The food-odor-evoked signal is transmitted via glutamatergic neurotransmission from AWC and through AMPA and kainate-like glutamate receptor subunits. In contrast, peptidergic signaling is required to generate preference between different food odors while being dispensable for the recognition of the odors. We show that this regulation is achieved by the neuropeptide NLP-9 produced in AWB, which acts with its putative receptor NPR-18, and by the neuropeptide NLP-1 produced in AWC. In addition, another set of sensory neurons inhibits food-odor preference. These mechanistic logics, together with a previously mapped neural circuit underlying food-odor preference, provide a functional network linking sensory response, transduction, and downstream receptors to process complex olfactory information and generate the appropriate behavioral decision essential for survival.
\end{abstract}

Key words: glutamatergic transmission; neuropeptide signaling; olfactory sensory neurons; olfactory sensory signaling; preference of food odors

\section{Introduction}

Olfactory preference among different foods is widely observed in vertebrates and invertebrates and can be influenced by many factors, including nutritional and behavioral states and developmental stage, as well as experience with the food odors (Mandairon et al., 2008; Ha et al., 2010; Fougeron et al., 2011; Saveer et al., 2012; Yoshida et al., 2012). However, the mechanisms whereby olfactory systems process either simultaneously or alternately presented food odors to exhibit behavioral preference remain largely unknown.

Previous work in different organisms, including the nematode Caenorhabditis elegans, has revealed the molecular mechanisms underlying primary olfactory sensory response, signaling transduction, and cellular events that are required to generate the appropriate odor-dependent behaviors (Juilfs et al., 1997; Chalasani et al., 2007; Pírez and Wachowiak, 2008; Root et al., 2008, 2011; Ignell et al., 2009; Petzold et al., 2009; Chalasani et al., 2010;

\footnotetext{
Received Dec. 31, 2013; revised April 24, 2014; accepted May 31, 2014.

Author contributions: G.H. and Y.Z. designed research; G.H., Y.S., H.H., A.D., S.W., and X.Z. performed research; G.H. analyzed data; G.H. and Y.Z. wrote the paper.

We thank the Caenorhabditis Genetics Center, which is funded by the National Institutes of Health (NIH) Office of Research Infrastructure Programs (Grant P40 00010440), Dr. C. Bargmann, Dr. V. Maricq, Dr. R. Komuniecki, and Dr. M. de Bono for strains; and J. Yu for the tax-4 genomic clone. The work in the Zhang laboratory was supported by the Esther and Joseph Klingenstein Fund, March of Dimes Foundation, the Alfred P. Sloan Foundation, the John Merck Fund, and NIH (Grant R01 DC009852 to Y.Z.).

Correspondence should be addressed to Yun Zhang at the above address. E-mail: yzhang@oeb.harvard.edu. DOI:10.1523/JNEUROSCI.0012-14.2014

Copyright $\odot 2014$ the authors $\quad 0270-6474 / 14 / 339389-15 \$ 15.00 / 0$
}

Hadley and Halliwell, 2010; Harris et al., 2010). These studies have provided a body of knowledge to address the mechanisms for food-odor preference.

C. elegans senses a plethora of environmental cues, including odorants, salts, pheromones, and temperature (Ward et al., 1975; Dusenbery et al., 1978; Bargmann et al., 1993). The well defined nervous system of the nematode offers an opportunity to study preference of food odors at molecular and cellular levels. Particularly, the AWB and AWC chemosensory neurons have been implicated in sensorimotor responses to food-associated odors. By using intracellular calcium imaging, these two neurons have also been shown to respond to the odors of bacteria, including the laboratory worm food Escherichia coli strain OP50 and a pathogenic strain Pseudomonas aeruginosa PA14 (Chalasani et al., 2007; Ha et al., 2010). We have previously found that under a standard condition, C. elegans prefers the smell of PA14 to the smell of OP50, and AWB and AWC are required for this olfactory preference. Using laser ablation, we have mapped a sensorimotor circuit downstream of AWB and AWC that regulates the olfactory preference of PA14 to OP50 (Ha et al., 2010). These results reveal a neuronal network underlying olfactory preference between two different foods, allowing for characterization of the molecular machinery and signaling pathways for food-odor recognition and preference.

Here, we characterize the sensory transduction underlying the recognition and preference between the smells of two bacterial foods for C. elegans, E. coli OP50 and P. aeruginosa PA14. We 
demonstrate that food-odor preference requires the olfactory sensory neurons AWB and AWC that use specific heterotrimeric $\mathrm{G} \alpha$-proteins, multiple guanylate cyclases, and cGMP-gated channel subunits. We show that downstream of olfactory sensory response, glutamatergic signaling from AWC regulates foododor recognition and peptidergic transmission from AWB and AWC mediates preference between two different food odors. These results extend our understanding of how olfactory sensory systems process multiple complex odors to produce behavioral responses that are essential for survival and demonstrate that distinct signaling pathways mediate recognition of food odors versus preference between the odors.

\section{Materials and Methods}

Culture and maintenance of strains. C. elegans hermaphrodites were used in this study. The Bristol N2 (the wild-type reference) strain of C. elegans was used as the control for all behavioral analysis and as the parental strain to produce transgenic animals. All animals were raised at $20^{\circ} \mathrm{C}$ under standard conditions (Brenner, 1974). Mutants used for the study include the following: FK100 tax-2(ks10)I, PR691 tax-2(p691)I, FK103 tax-4(ks28)III, PR678 tax-4(p678)III, CX3090 tax-2(p691)I; tax4(p678)III, CX10 osm-9(ky10)IV, CX2205 odr-3(n2150)V, MT4810 odr-3(n2046)V, MT6308 eat-4(ky5)III, MT150 egl-3(n150)V, KP2018 egl-21(n476)IV, JT609 eat-16(sa609)I, RB1780 rgs-3(ok2288)II, MT3113 tdc-1(n3419)II, MT9455 tbh-1(n3247)X, MT1241 egl-21(n611)IV, RB2030 nlp3(ok2688)X, RB1340 nlp-1(ok1470)X, RB1668 c02h7.2(ok2068)X, RB1429 t27d1.3(ok1626)III, RB982flp-21(ok889)V, IC683 npr-9(tm1652)X, RB1609 nlp5(ok1981)II, VC1309 nlp-8(ok1799)I, RB1372 nlp-18(ok1557)II, VC2324 flp-6(ok3056)V, DR47 daf-11(m47)V, KJ462 cng-1(ok3292)V, RB2407 cng-3(jh113)IV, CX2065 odr-1(n1936)X, PR694 tax-2(p694)I, RB1289 $n p r-18(o k 1388) X$, NL334 gpa-2(pk16)V, NL335 gpa-3(pk35)V, NL2330 gpa-13(pk1270)V, RB658 glc-4(ok212)II, VM487 nmr-1(ak4)II, RB1808 glr-2(ok2342)III, VC350 glc-2(gk179)I, CX5019 glr-1(ky176)III, KP4 glr1(n2461)III, XA7400 glc-3(ok321)V, DA1371 avr-14(ad1302)I, DA1051 avr-15(ad1051)V, DA1302 avr-14(ad1302)I; avr-15(ad1051)V, CX03572 $n l p-9(t m 3572) V$, and FX02984 nlp-7(tm2984)X (gifts from S. Mitani, Tokyo Women's Medical University, Tokyo, Japan).

Transgenic strains used in this study include the following: ZC1626 eat-4(ky5)III; yxEx1519 (Peat-4:eat-4; Punc-122::gfp), ZC1631 eat-4(ky5)III; yxEx807 [Podr-3::eat-4(cDNA); Punc-122:::gfp], ZC1629 eat-4(ky5)III; yxEx805 [Podr-3::eat-4(cDNA); Punc-122::gfp], ZC1628 eat-4(ky5)III; yxEx804 [Podr-3::eat-4(cDNA); Punc-122::gfp], ZC2419 eat-4(ky5)III; yxEx1263 [Pstr-1::eat-4(cDNA); Punc-122::gfp], ZC1964 eat-4(ky5)III, yxEx999 [Podr-1::eat-4(cDNA); Punc-122::gfp], ZC2114 yxEx1127 [Podr-1::egl-3RNAi; Punc-122::gfp], ZC2112 yxEx1125 [Podr-1::odr-1RNAi; Punc-122::gfp], ZC2154 yxEx1148 [Podr-1::daf-11RNAi; Punc-122::gfp], ZC2303 tax4(ks28)III; yxEx1205 [Ptax-4::tax-4, Punc-122::rfp].

Generation of transgenes and transgenic animals. Genomic DNA fragments for rescuing experiments were amplified from N2 genomic DNA by PCR using standard protocols and confirmed by sequencing.

To generate strains that express Podr-1::eat-4 and Pstr-1::eat-4 transgenes, a $4.7 \mathrm{~kb}$ promoter sequence of Pstr-1 and $2.4 \mathrm{~kb}$ promoter sequence of Podr-1 were amplified by PCR and cloned into pCR8 Gateway entry vector (Invitrogen), which were recombined with the $p S M-r f B$ eat-4 destination vector following the manufacturer's instructions (Invitrogen). All transgenes were confirmed by restriction digest and sequencing. Transgenic animals were generated by germ-line transformation (Mello et al., 1991). Transgenes were injected together with Punc-122::gfp or Punc-122::rfp plasmid, which is expressed in hermaphrodite coelomocytes and serves as a coinjection marker (Miyabayashi et al., 1999), at a total concentration of $20-50 \mathrm{ng} / \mu \mathrm{l}$. Multiple transgenic lines were examined in each experiment.

Generation of cell-specific RNAi constructs. Neuron-specific RNAi transgenes were constructed as described previously (Esposito et al., 2007; Harris et al., 2009). Briefly, a neuron-specific promoter was fused to an exon-rich region of the target gene (egl-3, odr-1, or daf-11) to generate both sense and antisense PCR fusion constructs. A $2.4 \mathrm{~kb} o d r-1$ promoter and a $4.7 \mathrm{~kb}$ str- 1 promoter were amplified for subsequent PCR fusion reactions (Troemel et al., 1995; L'Etoile et al., 2000). At least three fusion products for each target gene were pooled, and the mixture of the sense and antisense transgenes was injected at $25-100 \mathrm{ng} / \mu \mathrm{l}$ together with 25 ng/ $\mu$ P Punc-122::rfp or Punc-122:::gfp DNA into wild-type animals. Multiple transgenic lines were examined for each RNAi experiment.

Microdroplet assay. Microdroplet assay was performed as previously described with minor modifications (Ha et al., 2010). Briefly, $\sim 50$ hermaphrodites of L4-stage larvae were transferred from regular culture plates onto a fresh plate containing a lawn of E. coli OP50 during the night before the assay. On the following day, young adults were examined for olfactory behavior using microdroplet assay by comparing their turning rates in response to two alternating air streams. To quantify preference between two food odors, the air streams were saturated by the fresh liquid culture of E. coli OP50 or P. aeruginosa PA14. To measure the recognition of food odors, one air stream was odorized by passing though nematode growth media (NGM) and the other was saturated by the liquid culture of OP50 or PA14. OP50 and PA14 bacterial cultures were prepared by adding individual OP50 and PA14 bacterial colonies, respectively, into $40 \mathrm{ml}$ of NGM and allowed to grow overnight. The indexes for PA14 preference in the present study show some variations, such as the wild-type preference indexes in Figure 3. These variations are likely due to the variations among different batches of bacteria cultures, because the growth of the bacterial strains depends on environmental conditions, such as temperature and moisture. These variations can result in variations in the smell of bacterial cultures that were used as the odor sources in the microdroplet assays. To analyze the effects of exogenous octopamine or tyramine, NGM plates were prepared to contain either $4 \mathrm{~mm}$ tyramine or octopamine hydrochloride (Sigma-Aldrich) as previously described (Horvitz et al., 1982; Alkema et al., 2005; Wragg et al., 2007). On the day of the assay, young adults were transferred from regular OP50 plates to NGM plates containing $4 \mathrm{~mm}$ tyramine or octopamine for $30 \mathrm{~min}$ before their olfactory responses were measured in the microdroplet assay. Animals were placed on an unseeded plate for $1 \mathrm{~min}$ before being transferred to amine-containing plates to remove any adherent OP50 bacteria. Wildtype animals without treatment of tyramine or octopamine were used as controls.

Nonanone assay. Animals were assayed as previously described (Troemel et al., 1997). Briefly, nematodes were grown at $20^{\circ} \mathrm{C}$ on NGM plates that contained a lawn of $E$. coli OP50. A group of 50-100 adult animals were washed three times in S-basal and once in distilled water, and placed in the center of a square NGM assay plate, on the two opposite ends of which either two individual spots of nonanone (10\%, $1 \mu \mathrm{l}$ each) or ethanol (used as the solvent; Sigma-Aldrich, $1 \mu$ l each) were freshly placed. The space of each assay plate was divided into six equal sectors labeled as A-F and the positions of the worms on each assay plate were scored after $1 \mathrm{~h}$. An avoidance index was defined as the number of animals in the two sectors farthest away from nonanone minus the number of animals in the two sectors closest to nonanone and then normalized by the total number of worms in all sectors.

\section{Results}

\section{Different sensory neurons combinatorially regulate} food-odor preference

We have previously shown that animals cultivated on E. coli OP50, the common food for C. elegans in laboratories, prefer the smell of the P. aeruginosa strain PA14 to the smell of OP50 (Ha et al., 2010). To understand the molecular and circuit mechanisms that are needed to generate olfactory preference of PA14 to OP50, we used an automated assay to measure olfactory responses in individual swimming animals (Ha et al., 2010; see Materials and Methods). We transferred well fed L4-stage larvae onto a freshly prepared regular culture plate $12-15 \mathrm{~h}$ before assay to obtain synchronized adult animals (Fig. $1 A$ ). Each of these animals was then transferred into a $2 \mu$ l of droplet of NGM buffer in a semienclosed chamber. These animals, while swimming in the droplets of NGM buffer, were exposed to the two air streams that were saturated with either OP50 smell or PA14 smell and alternated 
A

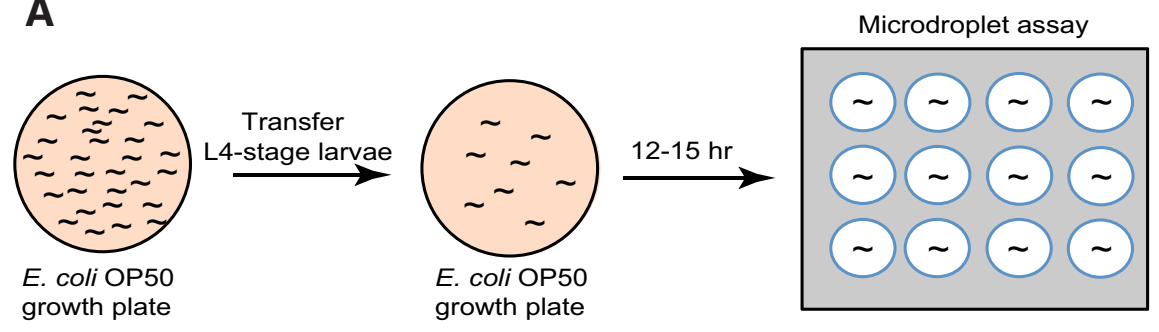

B OP50-saturated airstream PA14-saturated airstream

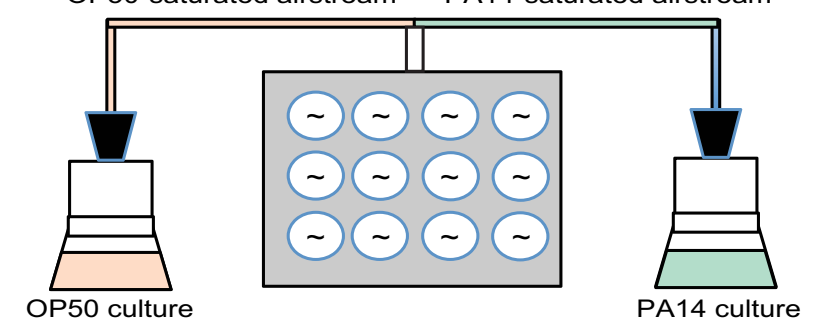

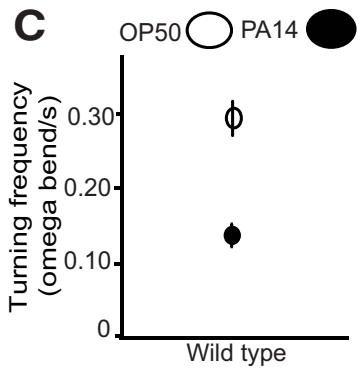

I(Turning frequency) $=$

Number of omega bends /Total assay time

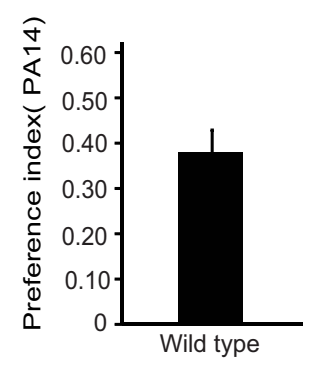

PA14 Preference index $=$ I(OP50)-I(PA14)/I(OP50)+I(PA14)
Figure 1. An automated microdroplet assay for sensorimotor responses to food odors. $A$, The protocol for measuring food-odor preference. $\boldsymbol{B}$, Schematic of the microdroplet assay for olfactory preference between two bacterial strains, E. coli OP50 and $P$. aeruginosa PA14. The sapphire window holds 12 droplets ( $2 \mu$ l each) of NGM buffer that contain individual young adults. The animals are subjected to two air streams that are odorized with the smell of $0 P 50$ or the smell of PA14 and alternate every $30 \mathrm{~s}$. The swimming behavior is recorded. The frequency of $\Omega$ bends is analyzed by a customized software and the PA14 preference index is calculated as indicated (See Materials and Methods). C, Sample turning frequency and PA14 preference index generated by multiple wild-type animal. Mean \pm SEM.

every $30 \mathrm{~s}$. The locomotory responses of the animals were recorded and measured by a customized software (Fig. $1 B, C$ ). It has been shown that, similar to worms crawling on a solid substrate, swimming worms regulate turning rate during olfactory sensorimotor responses (Pierce-Shimomura et al., 1999; Luo et al., 2008). During swimming, C. elegans continuously displays $\mathrm{C}$-shaped body bends that are stochastically interrupted by sharp body bends that resemble the shape of the Greek letter omega $(\Omega)$. Attractive odors suppress the rate of $\Omega$ bends and removal of attractants increases it. Thus, we used the rate of $\Omega$ bends evoked by olfactory cues to measure olfactory preference (Fig. $1 B, C$; see Materials and Methods). Consistent with our previous findings, animals raised on OP50 prefer the smell of PA14 in comparison with the smell of OP50 (Fig. 1).

Previously, using similar olfactory assays, we have shown that AWB and AWC olfactory sensory neurons play a critical role in generating the olfactory preference of PA14 over OP50 under standard conditions (Ha et al., 2010). AWC neurons mediate attractive olfactory responses via regulation of reversals and turns (Luo et al., 2008; Tsunozaki et al., 2008; Chalasani et al., 2010). In contrast, AWB neurons mediate avoidance of both repulsive odors and the lawn of certain pathogenic bacteria (Troemel et al.,
1997; Chao et al., 2004; Pradel et al., 2007). To understand the role of AWB and AWC in regulating food-odor preference, we examined the primary sensory transduction pathways that are known to regulate AWB-mediated and AWC-mediated sensorimotor behaviors (Coburn and Bargmann, 1996; Roayaie et al., 1998; L'Etoile et al., 2000). First, we examined the effects of mutations in predicted cyclic nucleotidegated channels in C. elegans, including the $\operatorname{tax}-2$ and tax- 4 genes that encode the $\alpha$ and $\beta$ subunits of the cGMP-gated cationic channels, respectively, as well as the cng-1 and cng-3 genes that encode cyclic nucleotide-gated channels (Coburn and Bargmann, 1996; Coburn et al., 1998; Komatsu et al., 1999; Cho et al., 2004, 2005). The TAX-2/TAX-4 channels are required for a broad range of sensory behaviors, including chemotaxis (Coburn and Bargmann, 1996; Komatsu et al., 1996; Coburn et al., 1998; Hallem et al., 2008; Bretscher et al., 2011; Hellman and Shen, 2011). We found that two loss-offunction mutations, $k s 10$ in tax-2 and $k s 28$ in tax-4, significantly disrupted the preference of the smell of PA14 in comparison with the smell of OP50 (Fig. 2A,B). These defects resulted from the inability of the tax -2 or tax -4 mutants to upregulate their turning rate in response to the less preferred smell of OP50 (Fig. 2A,B). The difference between the phenotypes in tax$2(k s 10)$ and $\operatorname{tax}-4(k s 28)$ may be due to the importance of each channel subunit in forming potential functional homodimeric channels that are required to generate PA14 preference. Consistently, the double mutant tax-2(p691); tax-4(p678), as well as each of the single mutants, all generated severely defective preference to PA14 (Fig. $2 I-L$ ). In contrast, both $c n g-1$ and $c n g-3$ mutants were wild-type for PA14 preference (Fig. 2E,F). In addition, a null mutation in osm-9, which encodes a TRPV (transient receptor potential vanilloid) channel in sensory neurons that do not express TAX-2/TAX-4 channels (Tobin et al., 2002), exhibited a wild-type PA14 odor preference (Fig. 2G,H). Expressing a genomic DNA fragment of tax -4 rescued the preference defect in the tax-4(ks28) mutants (Fig. 2C,D, Ptax-4::tax-4) and expressing the wild-type activity of TAX-4 in the AWC, AWB, and AWA neurons using the odr-3 promoter (Lesch and Bargmann, 2010) fully rescued the defect of the tax-4(ky791) mutants (Fig. 2C,D, Podr-3::tax-4). Interestingly, the full-length genomic tax-4 transgene generated an enhanced PA14 preference, suggesting that potential overexpression of tax-4 under its endogenous promoter may enhance PA14 preference. These results together demonstrate that the function of the cGMP-gated TAX-2/TAX-4 channels in the AWB and AWC sensory neurons are required to generate olfactory preference of PA14 in comparison with OP50.

To further examine the role of chemosensory neurons in food-odor preference, we tested another tax-2 mutant, p694, which has lost the expression of tax-2 only in a subset of sensory 

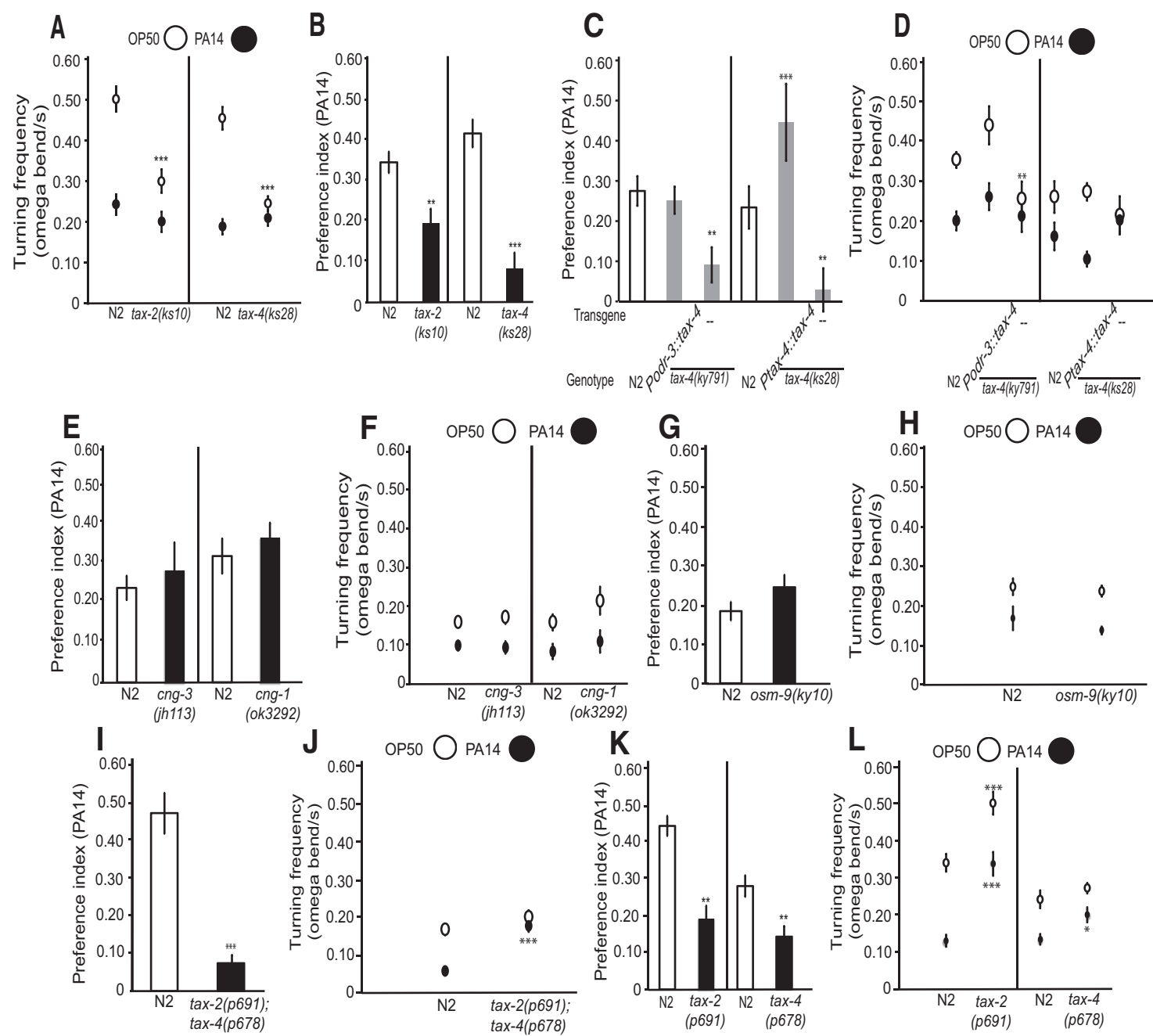

Figure 2. The GGMP-gated TAX-2/TAX-4 channel acts in the AWB and AWC sensory neurons to facilitate food-odor preference of PA14 to OP50. $A, B$, The tax-2(ks10) and tax-4(ks28) loss-offunction mutants are defective in preference of the smell of PA14 to the smell of OP50. C, D, Expressing the tax-4 genomic DNA rescues the preference defect in the tax- $4(\mathrm{ks} 28)$ mutants and selectively expressing a wild-type CDNA of tax-4 in the AWB and AWC neurons also rescues the preference defect in the tax-4(ky791) mutant animals. $\boldsymbol{E}-\boldsymbol{H}$, The cng-1(ok3292) and cng-3(jh113) mutants (E, $\boldsymbol{F})$, as well as the osm-9(ky10) mutants $(\mathbf{G}, \boldsymbol{H})$ are normal in olfactory preference between OP50 and PA14. $\boldsymbol{I}-\boldsymbol{L}$, The tax-2(p691);tax-4(p678) double mutants $(\boldsymbol{I}, \boldsymbol{J})$ and each of the single mutants $(\boldsymbol{K}, \boldsymbol{L})$ are severely defective in the olfactory preference of PA14 over OP50. In $J$, error bars are smaller than the size of the circles. For all, the transgenic animals and their nontransgenic siblings, as well as mutants, were compared with the wild-type control N2 measured in parallel, two-tailed Student's $t$ test. ${ }^{* * *} p \leq 0.001,{ }^{* *} p \leq 0.01,{ }^{*} p \leq 0.05$; no asterisk denotes no statistical difference $(p>0.05), n \geq 3$ assays, mean \pm SEM.

neurons, including ASE, AQR, AFD, and BAG. The tax-2(p694) mutant is defective in foraging on food, $\mathrm{CO}_{2}$ avoidance, and thermotaxis, but exhibits normal chemosensory responses to volatile chemicals and dauer-inducing cues (Coburn and Bargmann, 1996; Yook and Hodgkin, 2007; Hallem and Sternberg, 2008; Milward et al., 2011). Intriguingly, we found that the tax-2(p694) mutant animals were not only capable of preferring the smell of PA14, but also exhibited a significant increase in this preference (Fig. $3 A, B$ ). This increased preference was fully rescued by a full-length tax-2 genomic transgene or by the expression of a tax-2 cDNA in the ASE, AQR, BAG, and AFD sensory neurons (Fig. $3 C-F$ ), indicating that the TAX-2 channel subunit in all or some of these sensory neurons negatively regulates the preference of PA14 under these conditions. To identify the neurons that suppress the olfactory preference of PA14, we performed cellspecific rescuing experiments in the tax-2(p694) mutant animals. We found that expression of a tax-2 cDNA in either BAG or AQR, using the $f l p-17$ or $g c y-32$ promoter, respectively (Milward et al., 2011), rescued the increased PA14 preference in the tax-2(p694) mutants (Fig. $3 G-J$ ). However, expression of tax-2 in AFD or
ASE did not rescue (Fig. $3 K-N$ ). Further, selective expression of the egl-1 cDNA, which induces apoptosis (Conradt and Horvitz, 1998), in the BAG neuron also generated an enhanced preference of the PA14 smell, similar to the phenotype of the tax-2(p694) mutant animals (Fig. 3O). These results together indicate that the TAX-2-mediated signaling in either BAG or AQR negatively regulates the food-odor preference of PA14. Together, our findings indicate that $\mathrm{AWB}$ and $\mathrm{AWC}$ sensory neurons are required to generate the olfactory preference of PA14 and that BAG or AQR sensory neurons inhibit the preference. Combinatorial effects of these neurons fine-tune the preference between the smells of different foods.

\section{A G-protein signaling pathway mediates recognition of food odors}

After identifying the critical role of AWB and AWC olfactory sensory neurons in generating food-odor preference, we characterized the underlying mechanisms. It has been shown that the activity of TAX-2/TAX-4 channels is regulated by cGMP (Komatsu et al., 1999). Thus, we examined animals with mutations in the $\mathrm{G} \alpha$ subunits of heterotrimeric G-proteins that are expressed 

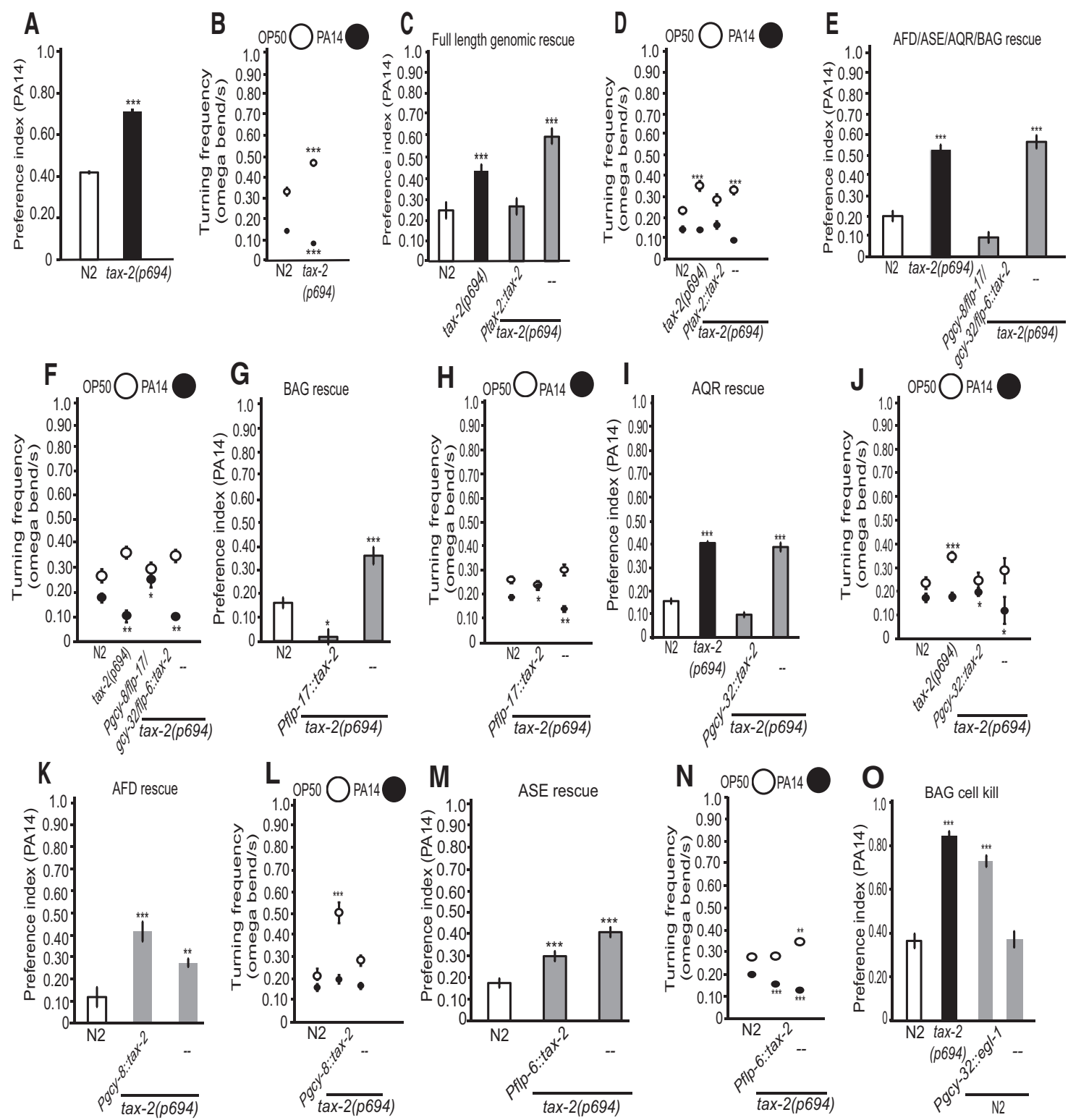

Figure 3. A subset of the tax-2-expressing neurons negatively regulates food-odor preference. $\boldsymbol{A}-\boldsymbol{D}$, The tax-2(p694) mutants that have lost the activity of TAX-2 in only a subset of the tax-2-expressing sensory neurons (BAG, AQR, AFD, and ASE) exhibit enhanced preference toward the smell of PA14 in comparison with the smell of 0P50 ( $\boldsymbol{A}, \boldsymbol{B})$ and expressing a full-length tax-2 genomic transgene rescues the enhanced PA14 preference in tax-2(p694) mutants (C, D). E-N, Expressing the wild-type tax-2 cDNA in the ASE (Pflp-6), AFD (Pgcy-8), BAG (Pflp-17), and AQR $(P g c y$-32) sensory neurons $(\boldsymbol{E}, \boldsymbol{F})$ or in BAG $(\boldsymbol{G}, \boldsymbol{H})$ or AQR $(\boldsymbol{I}, \boldsymbol{J})$ alone rescues enhanced PA14 preference in the tax-2(p694) mutants, but expressing the tax-2 $\mathrm{CDNA}$ in either AFD $(\boldsymbol{K}, \boldsymbol{L})$ or ASE $(\boldsymbol{M}, \boldsymbol{N})$ alone does not rescue. In $\boldsymbol{N}$, error bars are smaller than the size of the circles. $\boldsymbol{0}$, The animals that express the egl-1 CDNA in the BAG sensory neuron exhibit enhanced PA14 preference. For all, transgenic and nontransgenic siblings, as well as mutants, were compared with wild-type N2 animals that were examined in parallel, two-tailed Student's $t$ test. ${ }^{* * *} p \leq 0.001,{ }^{* *} p \leq 0.01$, ${ }^{*} p \leq$ $0.05 ;$ no asterisk denotes no statistical difference $(p>0.05), n \geq 4$ assays, mean \pm SEM.

in these sensory neurons. AWB sensory neurons strongly express a $\mathrm{G} \alpha$-protein that is encoded by $o d r-3$; AWC expresses many $\mathrm{G} \alpha$ subunits, including odr-3, gpa-2, gpa-3, gpa-5, gpa-6, and gpa-13 (Jansen et al., 1999; Lans et al., 2004). We first examined the role of $o d r-3$, which is essential for the sensory function of AWC and AWB (Roayaie et al., 1998; Lans et al., 2004; Yoshida et al., 2012). Consistently, two loss-of-function mutants of $o d r-3, n 2150$ and $n 2046$ (Roayaie et al., 1998) were both significantly defective in olfactory preference of PA14 to OP50 (Fig. 4A,B). We also examined the odr-3(ky879) gain-of-function mutant animals, which contained a missense mutation that changed the stability of GTP binding and produced a constitutively active G-protein (Lesch and Bargmann, 2010). Interestingly, the odr-3(ky879) mutant animals also exhibited a severely defective ability to prefer the smell of PA14 to the smell of OP50 (Fig. 4A,B), suggesting that appropriate amount of G-protein signaling is essential to generate odor preference of PA14. To further evaluate this possibility, we examined animals that lacked negative regulators of neuronal G-protein signaling, including eat-16 and rgs-3 (Hajdu-Cronin et al., 1999; Ferkey et al., 2007). Interestingly, the eat-16(sa609) mutants were severely defective for PA14 preference (Fig. 4I,J), whereas the rgs-3(ok2288) mutants exhibited wild-type olfactory preference (Fig. $4 K, L$ ). These results further characterized the potential G-protein signaling pathway involved in sensory transduction of food odors. In contrast, mutations in gpa-3 and gpa-13 (Lans et al., 2004; Burghoorn et al., 2010) did not seem to alter olfactory preference between PA14 and OP50 because both lossof-function mutants gpa-3(pk35) and gpa-13(pk1270) (Zwaal et 
A

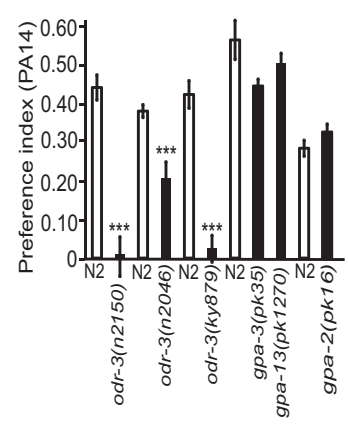

E

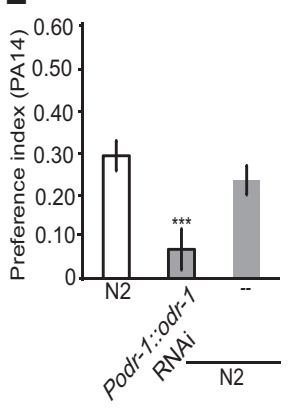

I

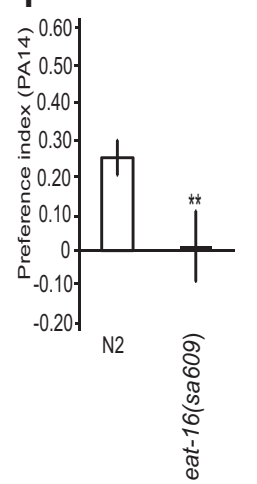

B

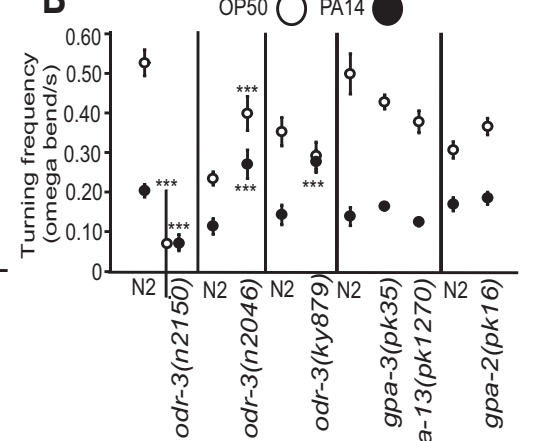

$\mathbf{F}$
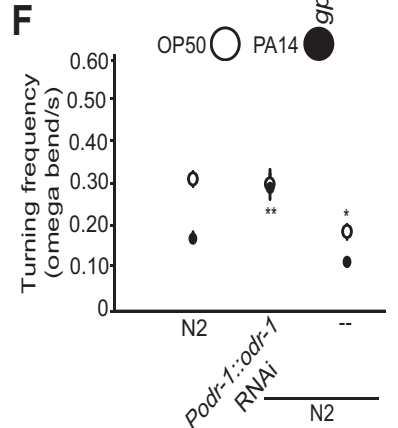
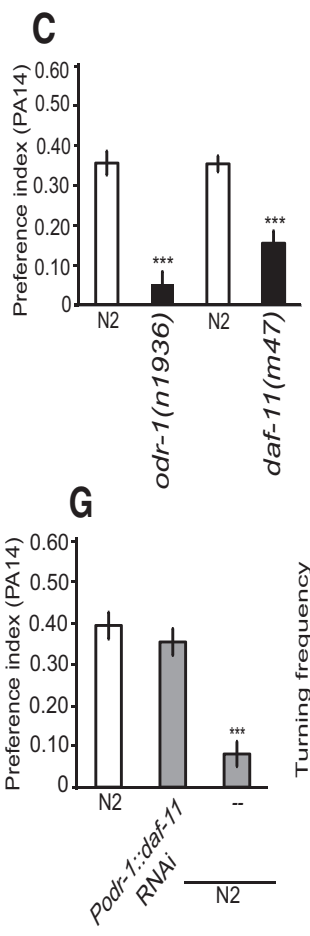

$\mathbf{D}_{0.60}{ }^{\mathrm{OP} 50 \mathrm{O}}{ }^{\mathrm{PA} 14}$
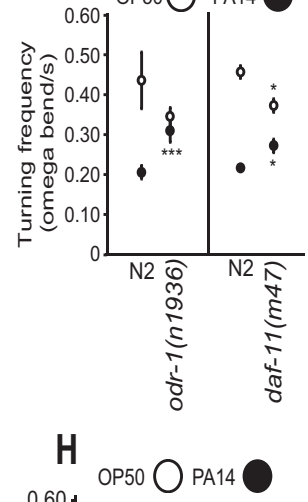
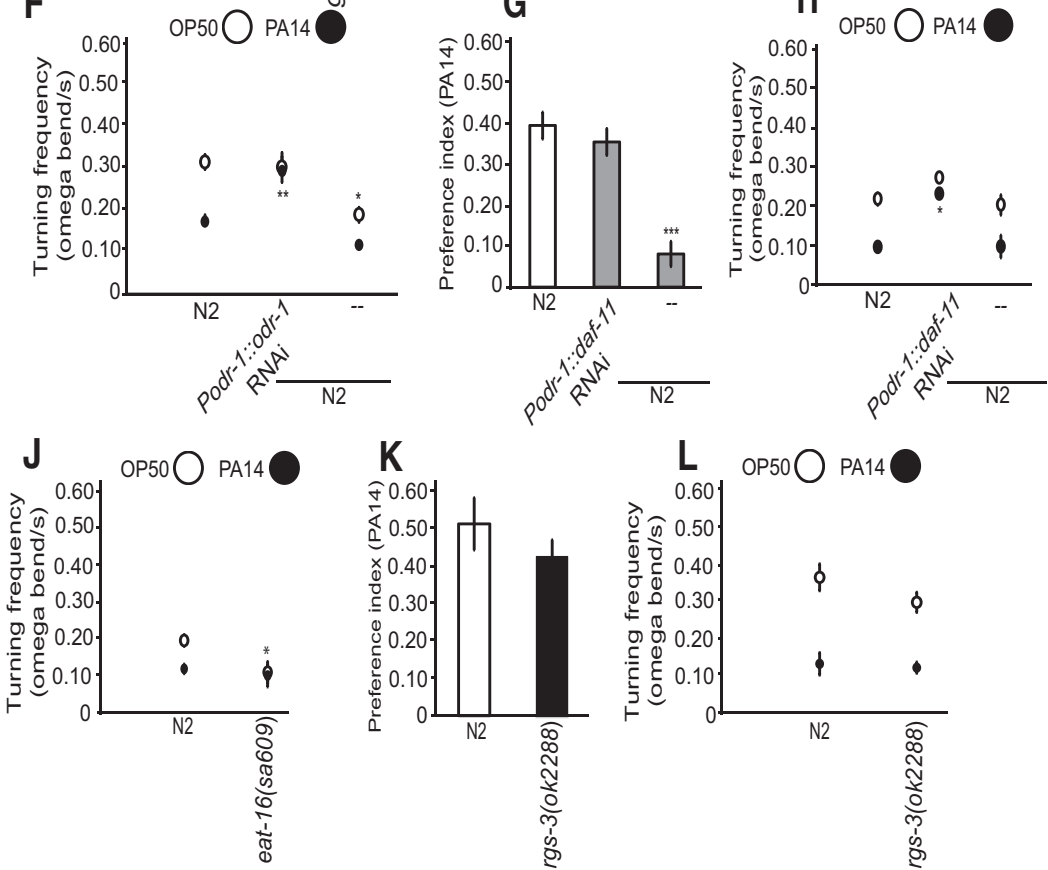

Figure 4. A G-protein signaling pathway regulates food-odor recognition. $\boldsymbol{A}, \boldsymbol{B}$, Two different mutations in the $\mathrm{G} \alpha$-encoding gene odr-3 disrupt olfactory preference of PA14 to $0 \mathrm{P} 50$, but mutating several other $\mathrm{G} \alpha$-encoding genes does not alter olfactory preference for PA14. C, D, Mutations in two genes that encode guanylyl cyclases odr-1 and daf- 11 disrupt the food-odor preference between PA14 and OP50. E-H, Selective knockdown of the odr-1 activity or the daf-11 activity in the AWB and AWC sensory neurons in wild-type animals abolishes the preference of PA14 smell to 0 P50 smell. $I-L$, Animals containing null mutations in eat-16 are defective in the olfactory preference of PA14 in comparison with 0 P50, but deleting rgs-3 does not alter PA14 preference. For all, transgenic animals and their nontransgenic siblings, as well as mutants, were compared with the wild-type N2 tested in parallel, two-tailed Student's $t$ test. ${ }^{* * *} p \leq 0.001,{ }^{* *} p \leq 0.01,{ }^{*} p \leq 0.05$; no asterisk denotes no statistical difference $(p>0.05), n \geq 3$ assays, mean \pm SEM.

al., 1997; Jansen et al., 1999) generated a wild-type odor preference between PA14 and OP50 (Fig. 4A,B). In addition, the gpa2-encoded $\mathrm{G} \alpha$-protein that negatively regulates AWC signaling (Lans et al., 2004) was also not required because the loss-of-function gpa-2(pk16) mutants exhibited wild-type PA14 preference (Fig. $4 A, B)$. Together, these results indicate that the ODR-3-mediated G-protein signaling is required to generate the olfactory preference of PA14 over OP50.

Next, we examined the role of guanylate cyclases. There are 34 guanylate cyclases in the C. elegans genome with either distinct or overlapping expression patterns in the nervous system (Yu et al., 1997). We examined two loss-of-function mutations, odr1 (n1936) and daf-11(m47). While odr-1 encodes a receptor guanylate cyclase and daf-11 encodes a cytoplasmic guanylate cyclase, both of them are expressed in the cilia of AWC and AWB to mediate chemotaxis (Vowels and Thomas, 1992; Schackwitz et al., 1996; Coburn et al., 1998; Bernhard and van der Kooy, 2000;
Birnby et al., 2000; L'Etoile and Bargmann, 2000; Murakami et al., 2001; Torayama et al., 2007; Mukhopadhyay et al., 2008; Liu et al., 2010). We found that both the odr-1(n1936) and daf-11(m47) mutant animals exhibited a defective preference between the PA14 smell and the OP50 smell (Fig. 4C,D). Consistently, knocking down the function of either odr-1 or daf-11 specifically in AWB and AWC generated similar defects in food-odor preference (Podr-1::odr-1RNAi, Podr-1::daf-11RNAi; Fig. 4E-H). Together, our analysis demonstrates that the ODR-1 and DAF-11 guanylate cyclases act together with the G $\alpha$-protein ODR-3 and the cGMP-gated TAX-2/TAX-4 channels in the AWB and AWC sensory neurons to produce food-odor preference.

Because recognizing food odor is a prerequisite of food-odor preference, we assessed the precise role of the G-protein signaling by analyzing the ability of the mutants in distinguishing food odors versus nonfood odors. Using the microdroplet assay, we found that wild-type C. elegans clearly distinguishes the smell of 
Table 1. Preference indexes ${ }^{a}$

\begin{tabular}{|c|c|c|c|}
\hline Genotype & NGMv0P50 & NGMvPA14 & 0Р50vPA14 \\
\hline \multicolumn{4}{|l|}{ Pair 1} \\
\hline N2 & $0.309( \pm 0.046)$ & $0.334( \pm 0.032)$ & $0.441( \pm 0.030)$ \\
\hline$o d r-3(n 2150)$ & $0.045( \pm 0.027)^{* * * *}$ & $0.094( \pm 0.041)^{* * * *}$ & $0.001( \pm 0.047)^{* *}$ \\
\hline \multicolumn{4}{|l|}{ Pair 2} \\
\hline N2 & $0.343( \pm 0.046)$ & $0.210( \pm 0.069)$ & $0.423( \pm 0.046)$ \\
\hline odr-3(ky879) & $0.088( \pm 0.045)^{* * *}$ & $0.008( \pm 0.027)^{* * *}$ & $0.024( \pm 0.045)^{* *}$ \\
\hline \multicolumn{4}{|l|}{ Pair 3} \\
\hline N2 & $0.372( \pm 0.044)$ & $0.322( \pm 0.024)$ & $0.355( \pm 0.020)$ \\
\hline daf-11(m47) & $-0.051( \pm 0.031)^{* * *}$ & $0.184( \pm 0.028)^{* * *}$ & $0.156( \pm 0.031)^{* *}$ \\
\hline \multicolumn{4}{|l|}{ Pair 4} \\
\hline N2 & $0.467( \pm 0.030)$ & $0.340( \pm 0.030)$ & $0.357( \pm 0.030)$ \\
\hline odr-1(n1936) & $0.039( \pm 0.029)^{* * *}$ & $0.034( \pm 0.015)^{* * *}$ & $0.053( \pm 0.032)^{* *}$ \\
\hline \multicolumn{4}{|l|}{ Pair 5} \\
\hline N2 & $0.347( \pm 0.041)$ & $0.485( \pm 0.053)$ & $0.414( \pm 0.034)$ \\
\hline $\operatorname{tax}-4(k s 28)$ & $0.012( \pm 0.034)^{* * *}$ & $0.118( \pm 0.015)^{* * *}$ & $0.081( \pm 0.040)^{* *}$ \\
\hline \multicolumn{4}{|l|}{ Pair 6} \\
\hline $\mathrm{N} 2$ & $0.342( \pm 0.046)$ & $0.392( \pm 0.038)$ & $0.30( \pm 0.020)$ \\
\hline eat-4(ky5) & $0.115( \pm 0.027)^{* * *}$ & $0.101( \pm 0.036)^{* * *}$ & $0.132( \pm 0.020)^{* *}$ \\
\hline \multicolumn{4}{|l|}{ Pair 7} \\
\hline N2 & $0.377( \pm 0.037)$ & $0.497( \pm 0.022)$ & $0.319( \pm 0.036)$ \\
\hline egl-3(n150) & $0.353( \pm 0.034) \mathrm{NS}$ & $0.594( \pm 0.020) \mathrm{NS}$ & $0.169( \pm 0.040)^{* *}$ \\
\hline \multicolumn{4}{|l|}{ Pair 8} \\
\hline N2 & $0.281( \pm 0.042)$ & $0.339( \pm 0.039)$ & $0.476( \pm 0.030)$ \\
\hline$n / p-1(0 k 1470)$ & $0.306( \pm 0.039) \mathrm{NS}$ & $0.335( \pm 0.040) \mathrm{NS}$ & $0.239( \pm 0.043)^{* *}$ \\
\hline \multicolumn{4}{|l|}{ Pair 9} \\
\hline N2 & $0.178( \pm 0.043)$ & $0.182( \pm 0.031)$ & $0.354( \pm 0.030)$ \\
\hline$n l p-9(\operatorname{tm} 3572)$ & $0.164( \pm 0.027) \mathrm{NS}$ & $0.185( \pm 0.024) \mathrm{NS}$ & $0.181( \pm 0.033)^{* *}$ \\
\hline \multicolumn{4}{|l|}{ Pair 10} \\
\hline N2 & $0.536( \pm 0.070)$ & $0.335( \pm 0.030)$ & $0.397( \pm 0.029)$ \\
\hline$n p r-18(0 k 1388)$ & $0.644( \pm 0.052) \mathrm{NS}$ & $0.290( \pm 0.037) \mathrm{NS}$ & $0.152( \pm 0.036)^{* *}$ \\
\hline
\end{tabular}

${ }^{a}$ The results in the column NGMvOP50 represent the olfactory preference of 0 P 50 over NGM buffer; the results in the column NGMvPA14 represent the olfactory preference of PA14 over NGM buffer; and the results in the column OP50vPA14 represent the olfactory preference of PA14 over OP50. All mutants were compared with $\mathrm{N} 2$ tested in parallel, two-tailed Student's $t$ test. ${ }^{* * *} p \leq 0.001$ represents statistical difference from N2. NS, No statistical difference $(p>0.05)$ from N2. $n \geq 3$ assays, mean ( \pm SEM).

bacteria from the smell of NGM medium and displays strong preference toward the smell of bacteria, whether it is generated by OP50 or PA14 (Table 1; see Materials and Methods). However, mutations in genes encoding the G-protein signaling components, including the $\mathrm{G} \alpha$ subunit ODR-3, the guanylate cyclases ODR-1 and DAF-11, and the cGMP-gated channel subunit TAX-4, severely disrupt the differential olfactory response toward the bacterial smells versus the smell of NGM medium, indicating that the G-protein signaling regulates food-odor preference by enabling recognition of the odors.

\section{The glutamatergic transmission from AWC regulates food-odor recognition}

After identifying the G-protein signaling that acts in AWB and AWC neurons to regulate food-odor recognition, we next sought the neurotransmission used by these neurons in mediating the olfactory response. Neurotransmission has been characterized in only a few C. elegans sensory neurons. For example, the polymodal ASH sensory neuron primarily uses glutamate to regulate aversive responses to noxious stimuli. Similarly, the olfactory neuron AWC signals via glutamatergic transmission to regulate sensorimotor responses to several attractants and food availability (Hart et al., 1999; Mellem et al., 2002; Chalasani et al., 2007, 2010; Harris et al., 2010). Because the glutamate vesicular transporter EAT-4 is expressed in both AWB and AWC (Lee et al., 1999; Chalasani et al., 2007; Ohnishi et al., 2011), we first examined the olfactory preference between OP50 and PA14 in a putative null mutant eat-4(ky5) (Lee et al., 1999). We found that the eat-4(ky5) mutant animals displayed a significantly lower preference toward PA14 and the defect was rescued by a wild-type eat-4 genomic DNA fragment (Fig. 5A-D). Thus, glutamatergic neurotransmission is needed to generate foododor preference of PA14 to OP50.

Next, to specify the role of the glutamatergic transmission in AWB and AWC neurons, we tested the rescuing effect of cellspecific expression of eat-4. We found that expressing a wild-type eat-4 cDNA in both AWB and AWC using the odr-1 promoter, which is selectively expressed in these neurons (L'Etoile et al., 2000), fully rescued the defect of odor preference in the eat$4(k y 5)$ mutant animals (Fig. $5 E, F)$. However, expressing eat-4 in AWB alone with the str-1 promoter did not rescue (Fig. $5 E, F$ ). In addition, knocking down the function of eat-4 in AWC and ASI, but not AWB, by expressing eat-4 RNAi using the $n l p-1$ promoter (Nathoo et al., 2001; Chalasani et al., 2010; Mills et al., 2012) produced a phenotype similar to the defect in the eat-4(ky5) mutant animals (Fig. 5G,H). Together, these results indicate that the glutamate neurotransmission from AWC sensory neurons is needed to generate the odor preference of PA14 to OP50. Furthermore, the eat-4(ky5) animals exhibited significant defects in distinguishing food odors generated by OP50 or PA14 from nonfood odors, i.e., the smell of NGM medium (Table 1). These results indicate that the glutamatergic signaling from AWC acts downstream of the G-protein signaling to regulate recognition of food odors, which functions as a prerequisite of odor preference.

\section{Peptidergic signals regulate preference between different food odors}

Next, we probed the possibility that AWB employs neuropeptidergic signaling to regulate the food-odor preference of PA14 to OP50. We first examined the phenotypes generated by loss-offunction mutations in egl-3 and egl-21, both of which encode broadly expressed neuropeptide-processing enzymes (Kass et al., 2001; Nathoo et al., 2001; Jacob and Kaplan, 2003). We found that the egl-3(n150) mutant animals were significantly defective in the olfactory preference for PA14 in comparison with OP50 (Fig. 6A,B). Consistently, two different loss-of-function mutations, egl-21(n476) and egl-21(n611), strongly reduced the olfactory preference of PA14 to OP50 [Fig. 6A, $B$; PA14 preference index: N2, $0.386 \pm 0.025$; egl-21(n476), $0.228 \pm 0.036(p \leq$ $0.001)$; turning rate to OP50 (per second): N2, $0.481 \pm 0.026$; egl-21(n476), $0.212 \pm 0.027$ ( $p \leq 0.01$ ); turning rate to PA14 (per second): N2, $0.213 \pm 0.017$; egl-21(n476), $0.133 \pm 0.018(p>$ $0.05)$; mean \pm SE, Student's $t$ test, $n>3$ assays]. Interestingly, egl-3(n150) mutants are normal in distinguishing food odors generated from either OP50 or PA14 from nonfood odors (Table $1)$. Together, these results indicate an essential role of neuropeptidergic signals in generating the food-odor preference of PA14 to OP50, but not in recognizing the food odors. To further implicate the neuropeptide signaling in AWB, we generated cell-specific RNAi of egl-3 in AWB alone and in both AWB and AWC (Pstr-1::egl-3RNAi, Podr-1::egl-3RNAi; Esposito et al., 2007; Mills et al., 2012). These transgenes significantly reduced the preference toward the smell of PA14 in comparison with the smell of OP50 (Fig. 6C-F), indicating that neuropeptides transmit the signaling output of AWB to mediate the food-odor preference.

To determine the neuropeptide(s) responsible for AWB output, we examined the effect of deletion mutations in two neuropeptide-encoding genes, $n l p-3(o k 2688)$ and $n l p-9(t m 3572)$ (Harris et al., 2010; Mills et al., 2012), because both $n l p-3$ and $n l p-9$ are expressed in AWB and have been previously demonstrated to modulate aversive responses to noxious stimuli (Nathoo et al., 2001; Harris et al., 2010; Mills et al., 2012). We found 
A

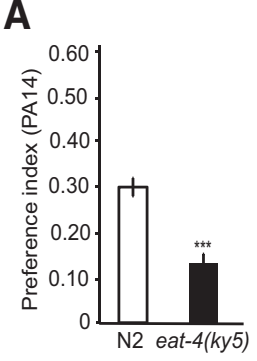

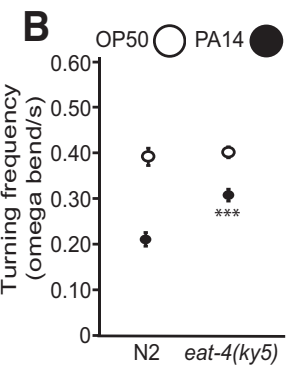

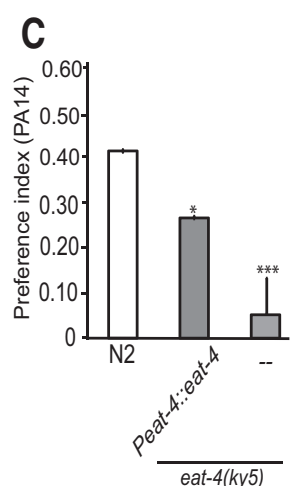

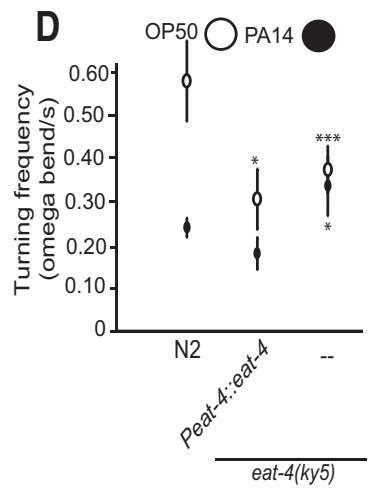
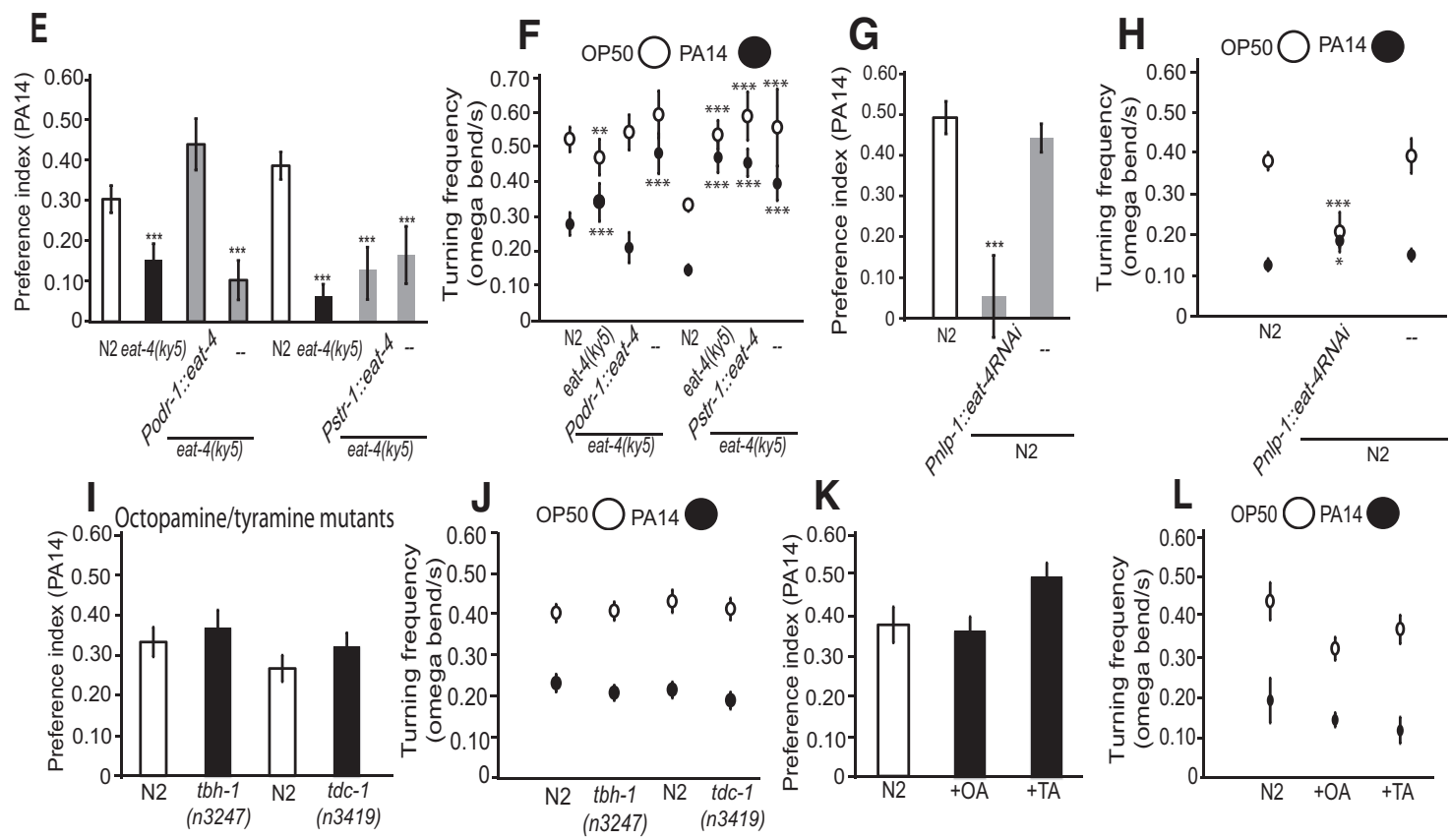

Figure 5. The AWC sensory neuron regulates food-odor recognition through glutamatergic neurotransmission. $A-F$, The loss of EAT-4 activity in the eat-4(ky5) mutants results in a loss of olfactory preference of PA14 to OP50 $(\boldsymbol{A}, \boldsymbol{B})$ and this defect is rescued by the expression of a genomic DNA of eat-4 $(\boldsymbol{C}, \boldsymbol{D})$ or selective expression of a wild-type eat-4 CDNA in the AWB and AWC sensory neurons $(\boldsymbol{E}, \boldsymbol{F}$, Podr-1::eat-4), but expressing the wild-type eat-4 CDNA in AWB alone does not rescue $(\boldsymbol{E}, \boldsymbol{F}$, Pstr-1::eat-4). $\boldsymbol{G}, \boldsymbol{H}$, Selective knockdown of eat-4 activity in AWC (Pnlp-1::eat-4RNAi) abolishes olfactory preference of PA14 to 0P50. I-L, Animals lacking $t d c-1$ or $t$ bh- 1 are wild-type in the olfactory preference of PA14 in comparison with 0P50 (I, $J)$, and application of exogenous tyramine or octopamine does not change the preference of PA14 over OP50 $(\boldsymbol{K}, \mathbf{L})$. For all, transgenic animals and their nontransgenic siblings, as well as mutants, were compared with the wild-type N2 animals tested in parallel, two-tailed Student's $t$ test. ${ }^{* * *} p \leq 0.001,{ }^{* *} p \leq 0.01,{ }^{*} p \leq 0.05 ;$ no asterisk denotes no statistical difference $(p>0.05), n \geq 3$ assays, mean \pm SEM.

that while $n l p-3(o k 2688)$ mutants displayed a wild-type preference for the smell of PA14 (data not shown), the nlp-9(tm3572) mutants were significantly defective (Fig. 6G,H). Consistent with the possibility that NLP-9 regulates preference of PA14 odors, the nlp-9(tm3572) mutants exhibited normal differential responses between food odors and nonfood odors (Table 1). NLP-9 is expressed in AWB neurons, in ASI neurons, in another four head neurons, in one tail neuron, and in non-neuronal cells (Nathoo et al., 2001; Fox et al., 2005). We found that reducing nlp-9 activity in AWB neurons by expressing cell-specific RNAi (Pstr-1::nlp-9RNAi; Mills et al., 2012) decreased the olfactory preference of PA14 over OP50, suggesting that NLP-9 produced from AWB regulates PA14 preference (Fig. $6 I, J$ ). In addition, several other neuropeptide mutants, $n l p-5, n l p-8, f l p-6, n l p-7$, and $f l p-21$ (Nathoo et al., 2001; Kim and Li, 2004; Bendena et al., 2008), were not defective in odor preference between OP50 and PA14. Together, these results indicate that the NLP-9-mediated neuropeptidergic signal regulates food-odor preference of PA14 over OP50.

In addition, by analyzing animals lacking the neuropeptide NLP-1, which was previously implicated in AWC-mediated ol- factory response to attractants (Chalasani et al., 2010), we addressed whether neuropeptide transmission from AWC also regulates PA14 preference. We found that the putative loss-offunction nlp-1(ok1470) mutant animals were defective in PA14 preference (Fig. $6 \mathrm{~K}, L)$. Similar to the $n l p-9(\operatorname{tm} 3572)$ mutants, the nlp-1(ok1470) mutants displayed a wild-type response in distinguishing food odors from nonfood odors (Table 1). In addition, we found that expressing the wild-type NLP-1 activity using the $o d r-3$ promoter that was primarily expressed in AWC fully rescued the defect of $n l p-1$ (ok1470) mutants in generating foododor preference of PA14 (Fig. 6M,N). Together, these results reveal that NLP-1 produced by AWC mediates food-odor preference between PA14 and OP50, whereas the glutamatergic signal from AWC regulates recognition of food odors.

Furthermore, we examined additional neurotransmitters that may play a role in olfactory preference between OP50 and PA14. First, we tested the $t d c-1$ (n3419) mutants, which harbor a deletion mutation in the tyrosine decarboxylase TDC-1 needed for the biosynthesis of tyramine and octopamine, as well as the $t b h$ 1(n3247) mutants, which have a deletion mutation in the gene 

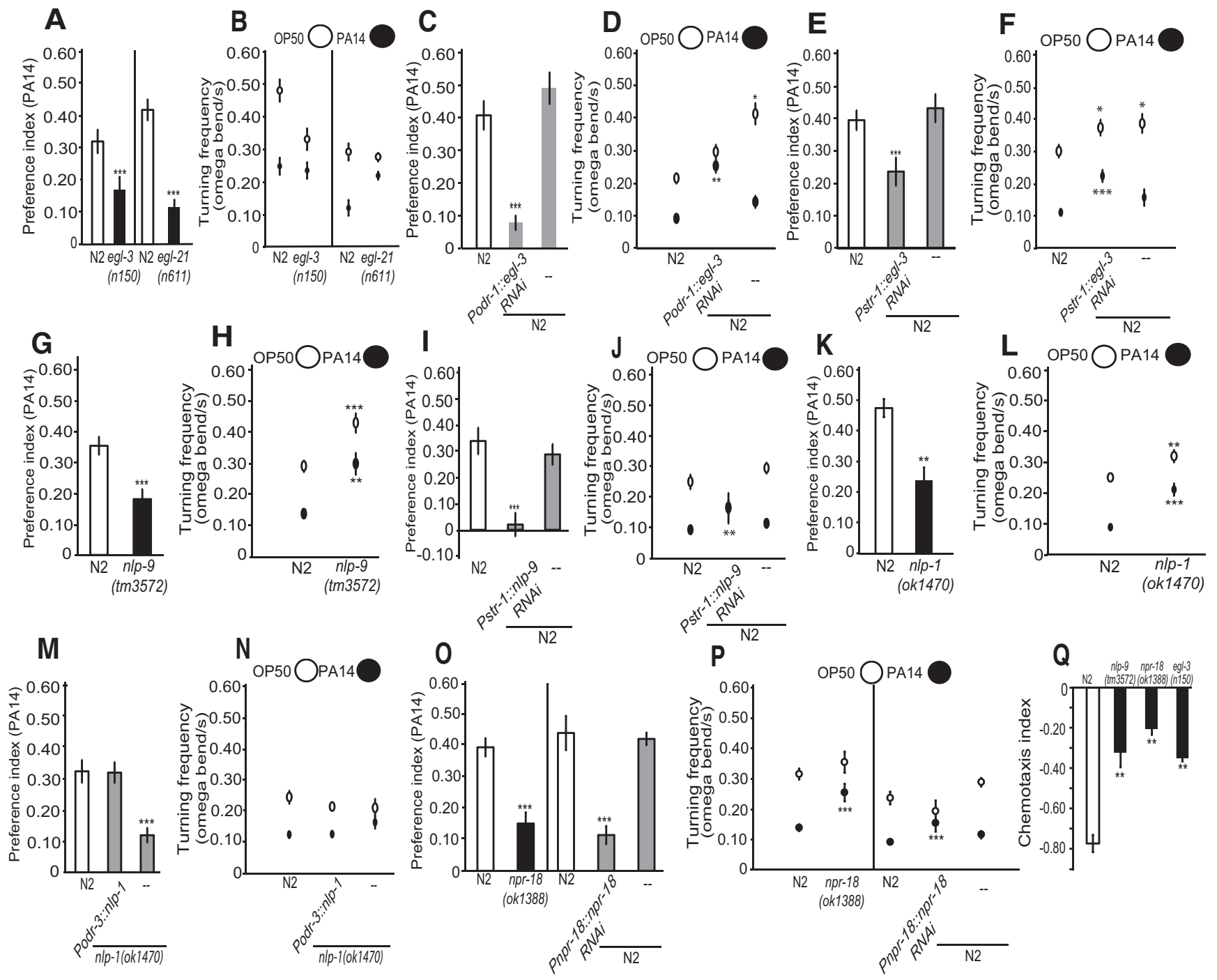

Figure 6. The AWB sensory neuron mediates PA14 odor preference via neuropeptidergic signaling. $A, B$, Mutations in genes that encode peptide-processing enzymes, egl-3 and egl-21, disrupt food-odor preference of PA14 to OP50. $\boldsymbol{C}-\boldsymbol{F}$, Selective knockdown of egl-3 activity in AWB and AWC (C, D, Podr-1::egl-3RNAi) or in AWB alone (E, $\boldsymbol{F}$, Pstr-1::egl-3RNAi) significantly reduces PA14 preference in wild-type animals. $\mathbf{G}, \boldsymbol{H}$, Deleting the AWB-expressing neuropeptide-encoding gene $n / p$ - 9 significantly reduces the olfactory preference of PA14 to 0 P 50 . I, J, Selective knockdown of the $n / p-9$ activity in AWB alone reduces the preference of the PA14 smell to OP50 smell. $K, L$, Deleting the AWC-expressing neuropeptide-encoding gene $n / p$ - 1 significantly reduces the food-odor preference of PA14 to OP50. $\boldsymbol{M}, \boldsymbol{N}$, Expressing the wild-type $n / p-1$ activity in AWC olfactory sensory neuron rescues the defect of the olfactory preference of PA14 in comparison with 0 P50 in nIp-1(ok1470) mutants. $\mathbf{O}, \mathbf{P}$, Loss of npr-18 or knocking down npr-18 activity decreases the food-odor preference of PA14 over OP50. Q, Mutations in $n / p-9$, $n p r-18$, and egl-3 significantly disrupt the aversive response to the repulsive odorant 2-nonanone, a response mediated by AWB sensory neurons. For all, transgenic animals and their nontransgenic siblings, as well as mutants, were compared with the wild-type N2 animals tested in parallel, two-tailed Student's t test. ${ }^{* * *} p \leq 0.001,{ }^{* *} p \leq 0.01,{ }^{*} p \leq 0.05 ;$ no asterisk denotes no statistical difference $(p>0.05), n \leq 3$ assays $(\boldsymbol{A}-\boldsymbol{P})$ or $n \geq 2$ separate days $(\mathbf{Q})$, mean \pm SEM.

encoding the tyramine $\beta$-hydroxylase needed for the biosynthesis of octopamine (Alkema et al., 2005; Wragg et al., 2007). Interestingly, both the $t d c-1(n 3419)$ and $t b h-1$ (n3247) mutants and the wild-type animals preincubated with $4 \mathrm{~mm}$ exogenous octopamine or tyramine (see Materials and Methods) showed wildtype olfactory preference between OP50 and PA14 (Fig. 5I-L). Dopamine and serotonin have been previously examined in PA14 preference (Ha et al., 2010). While serotonin plays a significant role in learned olfactory avoidance of PA14, it is not required for PA14 preference under the naive condition. The cat-2 mutants, which lack the dopamine synthesis enzyme, also did not affect PA14 preference (Ha et al., 2010). Together, our findings reveal the specific roles of glutamate neurotransmission and neuropeptide signaling in food-odor recognition and preference, respectively.
Multiple glutamate receptors mediate olfactory preference for food odors

Having identified glutamate as a neurotransmitter of AWC that regulates recognition of food odors generated by OP50 and PA14, we next sought the downstream signaling. We examined the olfactory preference between OP50 and PA14 in the loss-offunction mutants of a series of AMPA/kainate-like glutamate receptor subunits, NMDA-like receptor subunits, or glutamategated chloride channel subunits ( $g l r-1, g l r-2, n m r-1, g l c-2, g l c-3$, glc-4, avr-14, and avr-15). However, none of these single mutants exhibited any significant defect (Fig. $7 A, B$ ). Interestingly, the double mutants $g l r-1(k y 176) ; g l r-2(a k 10)$ and $g l r-1(k y 176) ; n m r-$ 1(ak4) (Mellem et al., 2002) were severely defective in generating the olfactory preference of PA14 in comparison with OP50 (Fig. $7 C, D)$. In contrast, the double mutant $g l r-1(n 2461) ; g l c-3(o k 321)$ 
A
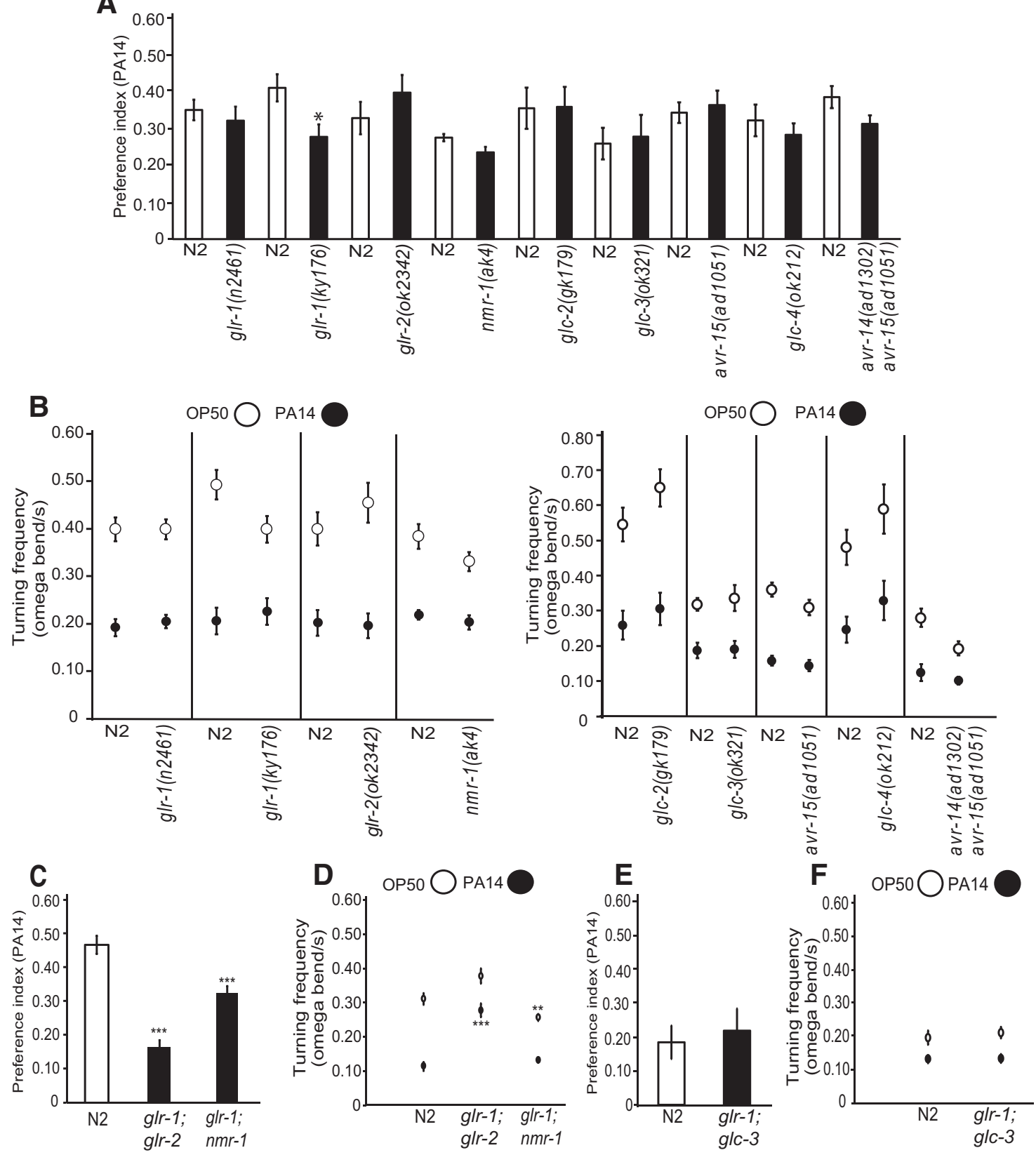

Figure 7. Combinatorial effects of multiple glutamate receptors on food-odor response to PA14 and OP50. $A, B$, Single mutations in a series of genes that encode glutamate receptors do not alter food-odor preference for PA14. C, D, The double mutants glr-1; glr-2 and glr-1;nmr-1 reduce PA14 preference. $\boldsymbol{E}, \boldsymbol{F}$, The double mutant $g / r-1 ; g / c-3$ exhibits wild-type PA14 preference. For all, transgenic animals and their nontransgenic siblings, as well as mutants, were compared with wild-type N2 animals tested in parallel, two-tailed Student's $t$ test. ${ }^{* * *} p \leq 0.001,{ }^{* *} p \leq 0.01,{ }^{*} p \leq$ $0.05 ;$ no asterisk denotes no statistical difference $(p>0.05), n \leq 3$ assays, mean \pm SEM.

(Chalasani et al., 2007) displayed normal olfactory preference of PA14 to OP50, suggesting that specific disruption of glutamatergic transmission in $g l r-1(k y 176)$; $g l r-2(a k 10)$ or $g l r-1(k y 176)$; $n m r-1$ (ak4) mutants disrupts the food-odor preference and the general reduction in the glutamate signaling cannot account for the defects in these receptor mutants. These results suggest that glutamatergic signaling mediates the food-odor response via multiple glutamate receptor subunits.

\section{Neuropeptide receptor NPR-18 mediates food-odor preference}

Having identified NLP-9 as the peptidergic output of AWB sensory neuron in mediating food-odor preference between OP50 and PA14 bacteria strains, we next sought the downstream neuropeptide receptor. We first examined the effect of a putative loss-of-function mutation in $n p r-18$, which has been shown to act as a potential receptor for NLP-9 (Mills et al., 2012). We found that the npr-18(ok1388) mutants were defective in generating the preference of the smell of PA14 in comparison with the smell of OP50 (Fig. 6O,P). Consistently, wild-type animals that expressed an $n p r-18$-RNAi with the $n p r-18$ promoter (Esposito et al., 2007; Mills et al., 2012) were also defective for PA14 preference (Pnpr-18::npr-18RNAi; Fig. 6O,P). In contrast, mutations in other neuropeptide receptor-encoding genes known to be expressed in sensory neurons, such as $n p r-9(t m 1652)$ and $n p r-$ 19(ok2068), showed wild-type preference for food odors (data 
A

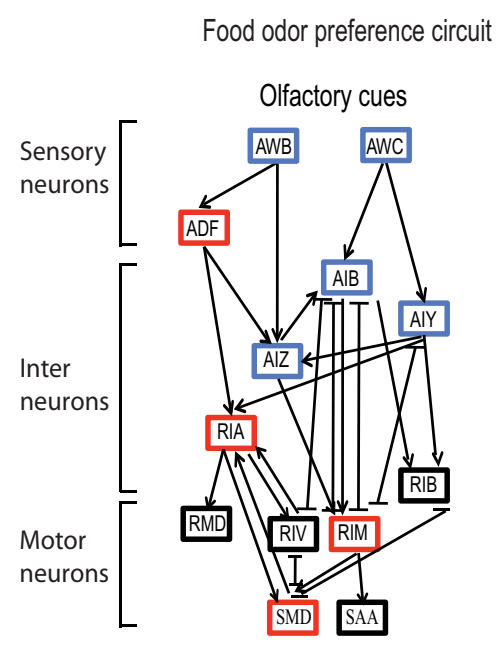

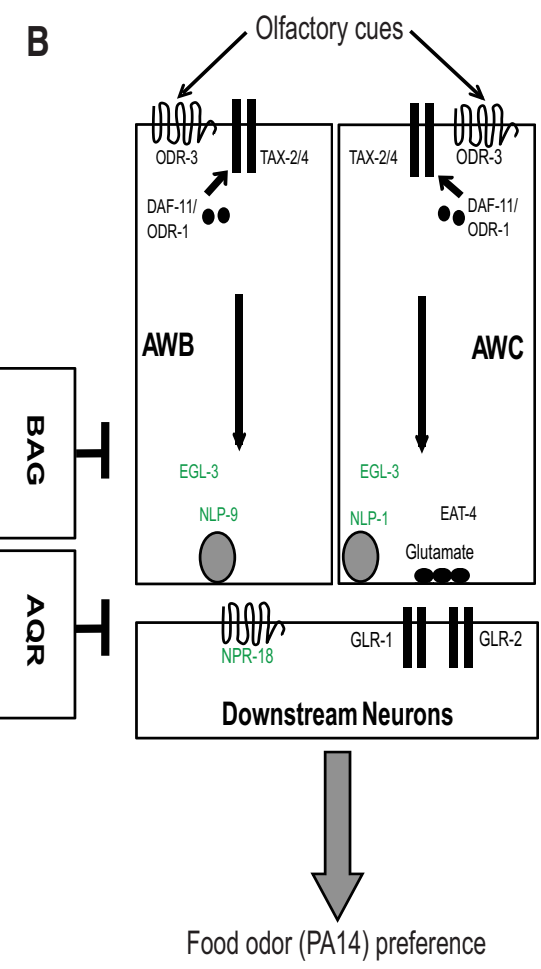

Gene Mammalian homologue

tax-2 cGMP-gated channel subunit

tax-4 cGMP-gated channel subunit

odr-3 G protein alpha subunit

odr-1 Guanylate cyclase

daf-11 Guanylate cyclase

eat-4 Glutamate vesicular loader

n/p-1 Neuropeptide-like

n/p-9 Neuropeptide-like

npr-18 Neuropeptide-like receptor

glr-1 Glutamate receptor subunit

glr-2 Glutamate receptor subunit

Figure 8. The signaling pathways underlying the olfactory preference of PA14 to OP50. A, Diagram represents the neuronal network for naive and learned olfactory preference for PA14 over $0 \mathrm{P} 50$ (Ha et al., 2010). Anatomically, the network consists of the major olfactory sensory neurons AWB and AWC, as well as the downstream interneurons and motor neurons that mediate head bending. Functionally, our analysis has shown that neurons highlighted in blue regulate olfactory preference of PA14 in naive animals (i.e., animals cultivated with OP50 as food) and neurons highlighted in red mediate learned preference of PA14 after training with PA14. Arrows and lines denote chemical and electrical synapses, respectively. $\boldsymbol{B}$, The AWC/AWB signal transduction and neurotransmission pathways that regulate the recognition and preference of the odors generated by $E$. coli OP50 and P. aeruginosa PA14. C. elegans genes implicated in food-odor recognition and preference and their mammalian homologues are shown on the right. In the schematic, the genes in black font are required for food-odor recognition and the genes in red font are specifically required for only food-odor preference.

not shown), supporting the specific effect of $n p r-18$ (ok1388). Consistently, the npr-18(ok1388) mutants distinguished food odors from nonfood odors similarly to wild-type animals (Table 1). In addition, both $n l p-9(t m 3572)$ and $n p r-18($ ok1388) mutants are defective in avoiding 2-nonanone, an aversive response mediated by AWB (Troemel et al., 1997), further demonstrating the role of NLP-9 and NPR-18 in AWB-mediated sensorimotor responses (Fig. 6Q). Together, these results show that AWB mediates food-odor preference through the NLP-9 peptide signal and the NPR-18 receptor.

\section{Discussion}

Many animals use olfactory cues to locate preferred food sources. While the conserved signaling pathway underlying olfactory sensorimotor response is well characterized, how the signaling pathways process more naturalistic olfactory cues, such as those generated by foods, has not been systematically examined. Here, we combine quantitative behavior analysis with genetic approaches to characterize the signaling molecules and neurotransmitters that regulate recognition and preference of food odors generated by two different bacteria strains, E. coli OP50 and $P$. aeruginosa PA14, in C. elegans. Our results elucidate the molecular and cellular attributes that allow the nervous system to generate behavioral preference among different food odors (Fig. 8).

Olfactory preference for food odors requires a combination of olfactory sensory neurons

Odorants may stimulate or inhibit different sensory neurons to generate appropriate behavioral responses, which depend on the nature, concentration, and, sometimes, context of the stimuli (de Bruyne et al., 1999; Vogler and Schild, 1999; Kuebler et al., 2011; Yoshida et al., 2012). Previously, we demonstrated that AWB and AWC neurons are required for the preference of the smell of $P$. aeruginosa PA14 in comparison with the smell of E. coli OP50 $(\mathrm{Ha}$ et al., 2010). Here, we show that AWB and AWC sensory neurons facilitate this preference by mediating the recognition of food odors through the cGMP-gated TAX-2/TAX-4 channel and G $\alpha$ subunit ODR-3, which are known to regulate sensory function of both neurons. Previously, it has been shown that AWC regulates the rate of reversals and turns in response to food availability (Bargmann et al., 1993; Wakabayashi et al., 2004; Gray et al., 2005; Chalasani et al., 2007, 2010; Ha et al., 2010; Yoshida et al., 2012) and AWB regulates avoidance of pathogenic bacterial lawns (Troemel et al., 1997; Pradel et al., 2007; Ha et al., 2010). Together, these results suggest that AWB and AWC sense complex bacterial odors to coordinate behavioral responses. Intriguingly, we have identified a negative role of the sensory neurons BAG and AQR in generating olfactory preference of PA14 over OP50, which may regulate the sensory neurons AWB and AWC and/or downstream circuit to produce the preference (Fig. 8). These results reveal a mechanism by which a network of olfactory neurons processes olfactory inputs to generate preference.

\section{A G $\boldsymbol{\alpha}$ signaling pathway regulates food-odor recognition}

Previous studies in both invertebrates and vertebrates have characterized the molecular mechanisms that mediate sensory response to olfactory stimuli. However, the function of these signaling molecules for detecting and distinguishing complex ol- 
factory cues, such as food odors, is not clear (Root et al., 2008, 2011; Ignell et al., 2009; Martin and Hildebrand, 2010; Das et al., 2011). In this study, we characterize the role of transduction molecules within the AWB and AWC sensory neurons in generating behavioral response to the smells of two worm foods, PA14 and OP50.

The C. elegans ODR-3 G $\alpha$ subunit, the DAF-11 and ODR-1 guanylate cyclases, and the TAX-2/TAX-4 cGMP-gated channels are part of the primary machinery that regulates olfactory responses to attractive volatiles, such as benzaldehyde and isoamyl alcohol, which are detected by the AWC neurons. These molecules are also required for AWB-mediated aversive responses to a volatile repellent, 2-nonanone, and to a bacterially produced surfactant, the serrawettin W2 (Coburn and Bargmann, 1996; Coburn et al., 1998; Roayaie et al., 1998; Birnby et al., 2000; L'Etoile and Bargmann, 2000; Pradel et al., 2007). Our results show that these same signaling transduction molecules in AWB and AWC are required for the olfactory preference of PA14 over OP50 by mediating the recognition of the food odors. Disrupting the signaling components in this pathway not only disrupts preference between different food odors, but also disrupts the ability to distinguish food odors from nonfood odors. Particularly, we propose that the ODR-3 G $\alpha$ subunit is the primary olfactory $\mathrm{G} \alpha$ subunit protein in this food-odor response. These results reveal the function of a G-protein-dependent cGMP-signaling pathway in regulating behavioral response to complex food odors.

\section{Glutamatergic neurotransmission mediates food-odor recognition}

In C. elegans, glutamate is the primary synaptic neurotransmitter for various chemotactic responses that are mediated by sensory neurons, including AWC and ASH (Hart et al., 1995; Mellem et al., 2002; Chalasani et al., 2007, 2010). Here, we show that the EAT-4-dependent glutamatergic transmission from the AWC sensory neuron regulates recognition of food odors, a requirement for the generation of food-odor preference. In crawling animals, the glutamatergic neurotransmission from AWC suppresses reversals in response to attractive odors (Chalasani et al., 2007). Here, we show that AWC-glutamate signal also plays a critical role in suppressing turning rate in swimming animals in response to the preferred PA14 smell, suggesting a general role for EAT-4-dependent glutamate signaling in regulating attractive sensorimotor responses. Further, we have shown that two AMPA receptor-like glutamate receptors, GLR-1 and GLR-2, are required to regulate food-odor preference between OP50 and PA14. Whereas $g l r-1$ has been implicated in many sensoryevoked behaviors, $g l r-2$ appears to play a role in only a few (Hart et al., 1995, 1999; Zheng et al., 1999; Brockie et al., 2001; Mellem et al., 2002; Chao et al., 2004; Chalasani et al., 2007). Combination of $g l r-1$ and $g l r-2$ regulates dopamine-dependent increase in turning rate acutely induced by removal of food (Hills et al., 2004; Gray et al., 2005). Here, we show that $g l r-1$ and $g l r-2$ play redundant roles in generating food-odor preference of PA14. While removing the function of either $g l r-1$ or $g l r-2$ does not alter the food-odor preference, losing both receptors abolishes the response. Further, similar to the effect of removing eat-4, combining mutations in $g l r-1$ and $g l r-2$ generates defects in suppressing turns in response to PA14 (Fig. 7C,D), consistent with the possibility that GLR-1 and GLR-2 act downstream of the EAT-4dependent signaling in generating PA14 preference. The expression patterns of $g l r-1$ and $g l r-2$ partially overlap (Brockie et al., 2001; Hills et al., 2004), suggesting that GLR-1 and GLR-2 may act independently of each other to provide functional redundancy during integration of food odors.

Glutamate acts as a primary transmitter in olfactory systems to convey sensory information to downstream projecting neurons; and neuropeptides often modulate olfactory sensorimotor response by regulating sensitivity, acuity, and plasticity (Chalasani et al., 2007, 2010; Ignell et al., 2009; Harris et al., 2010; Root et al., 2011). In rodents, glutamatergic signaling conveys odor information to mitral cells, tufted cells, and local inhibitory neurons (Berkowicz et al., 1994; Ennis et al., 1996, 2006). In fruit flies, glutamate acts as an inhibitory neurotransmitter to coordinate antennal lobe responses (Liu and Wilson, 2013). In zebrafish, glutamate acts as an excitatory neurotransmitter to transmit olfactory signaling to the olfactory bulb (Edwards and Michel, 2002). Here, we show that glutamate plays a critical role in distinguishing complex food odors from nonfood odors, expanding the signaling function of glutamate in regulating olfactory sensorimotor responses.

\section{Neuropeptides mediate food-odor preference, but not recognition}

Neuropeptides have been implicated in olfactory behavior and plasticity in both invertebrates and vertebrates. For example, in rats, insulin and leptin modulate spontaneous and odorantevoked activity of olfactory sensory neurons (Savigner et al., 2009). In Ambystoma mexicanum, neuropeptide $Y$ regulates the activity of the olfactory epithelium in response to hunger (Mousley et al., 2006). In Drosophila melanogaster, neuropeptide F and insulin regulate nutrition-dependent effects on avoidance of noxious foods and olfaction-driven food searching (Wu et al., 2005; Root et al., 2011). Tackykinin-related neuropeptides mediate presynaptic inhibition of olfactory sensory neurons during odor-evoked responses (Winther et al., 2006; Ignell et al., 2009). Similarly, in C. elegans, neuropeptides are critical modulators of olfaction (Bendena et al., 2008; Cohen et al., 2009; Chalasani et al., 2010; Harris et al., 2010, 2011; Mills et al., 2012; Chen et al., 2013). Here, we show that the NLP-9 signal from the AWB neurons and the somatostatin-like neuropeptide receptor NPR-18 regulate olfactory preference for PA14 in comparison with OP50. In addition, AWC signals through the buccalin-like neuropeptide NLP-1 to regulate the olfactory preference. We further extended the significance of these findings by demonstrating that NLP-1, NLP-9, and NPR-18 are not required for the recognition of food odors. These results together reveal that AWC sensory neurons employ glutamate neurotransmission to process sensorimotor response to food odors and AWB/AWC neurons use neuropeptides to modulate olfactory response to generate preference between the odors (Fig. $8 B$ ). Thus, our study provides a framework for understanding how sensory systems integrate complex odors at the molecular and cellular level to generate defined behavioral outputs.

\section{References}

Alkema MJ, Hunter-Ensor M, Ringstad N, Horvitz HR (2005) Tyramine functions independently of octopamine in the Caenorhabditis elegans nervous system. Neuron 46:247-260. CrossRef Medline

Bargmann CI, Hartwieg E, Horvitz HR (1993) Odorant-selective genes and neurons mediate olfaction in C. elegans. Cell 74:515-527. CrossRef Medline

Bendena WG, Boudreau JR, Papanicolaou T, Maltby M, Tobe SS, Chin-Sang ID (2008) A Caenorhabditis elegans allatostatin/galanin-like receptor NPR-9 inhibits local search behavior in response to feeding cues. Proc Natl Acad Sci U S A 105:1339-1342. CrossRef Medline

Berkowicz DA, Trombley PQ, Shepherd GM (1994) Evidence for glutamate 
as the olfactory receptor cell neurotransmitter. J Neurophysiol 71:25572561. Medline

Bernhard N, van der Kooy D (2000) A behavioral and genetic dissection of two forms of olfactory plasticity in Caenorhabditis elegans: adaptation and habituation. Learn Mem 7:199-212. CrossRef Medline

Birnby DA, Link EM, Vowels JJ, Tian H, Colacurcio PL, Thomas JH (2000) A transmembrane guanylyl cyclase (DAF-11) and Hsp90(DAF-21) regulate a common set of chemosensory behaviors in Caenorhabditis elegans. Genetics 155:85-104. Medline

Brenner S (1974) The genetics of Caenorhabditis elegans. Genetics 77:71-94. Medline

Bretscher AJ, Kodama-Namba E, Busch KE, Murphy RJ, Soltesz Z, Laurent P, de Bono M (2011) Temperature, oxygen, and salt-sensing neurons in $C$. elegans are carbon dioxide sensors that control avoidance behavior. Neuron 69:1099-1113. CrossRef Medline

Brockie PJ, Madsen DM, Zheng Y, Mellem J, Maricq AV (2001) Differential expression of glutamate receptor subunits in the nervous system of Caenorhabditis elegans and their regulation by the homeodomain protein UNC-42. J Neurosci 21:1510-1522. Medline

Burghoorn J, Dekkers MP, Rademakers S, de Jong T, Willemsen R, Swoboda P, Jansen G (2010) Dauer pheromone and G-protein signaling modulate the coordination of intraflagellar transport kinesin motor proteins in C. elegans. J Cell Sci 123:2077-2084. CrossRef Medline

Chalasani SH, Chronis N, Tsunozaki M, Gray JM, Ramot D, Goodman MB, Bargmann CI (2007) Dissecting a circuit for olfactory behaviour in Caenorhabditis elegans. Nature 450:63-70. CrossRef Medline

Chalasani SH, Kato S, Albrecht DR, Nakagawa T, Abbott LF, Bargmann CI (2010) Neuropeptide feedback modifies odor-evoked dynamics in Caenorhabditis elegans olfactory neurons. Nat Neurosci 13:615-621. CrossRef Medline

Chao MY, Komatsu H, Fukuto HS, Dionne HM, Hart AC (2004) Feeding status and serotonin rapidly and reversibly modulate a Caenorhabditis elegans chemosensory circuit. Proc Natl Acad Sci U S A 101:15512-15517. CrossRef Medline

Chen Z, Hendricks M, Cornils A, Maier W, Alcedo J, Zhang Y (2013) Two insulin-like peptides antagonistically regulate aversive olfactory learning in C. elegans. Neuron 77:572-585. CrossRef Medline

Cho SW, Choi KY, Park CS (2004) A new putative cyclic nucleotide-gated channel gene, cng-3, is critical for thermotolerance in Caenorhabditis elegans. Biochem Biophys Res Comm 325:525-531. CrossRef Medline

Cho SW, Cho JH, Song HO, Park CS (2005) Identification and characterization of a putative cyclic nucleotide-gated channel, CNG-1, in C. elegans. Mol Cells 19:149-154. Medline

Coburn CM, Bargmann CI (1996) A putative cyclic nucleotide-gated channel is required for sensory development and function in C. elegans. Neuron 17:695-706. CrossRef Medline

Coburn CM, Mori I, Ohshima Y, Bargmann CI (1998) A cyclic nucleotidegated channel inhibits sensory axon outgrowth in larval and adult Caenorhabditis elegans: a distinct pathway for maintenance of sensory axon structure. Development 125:249-258. Medline

Cohen M, Reale V, Olofsson B, Knights A, Evans P, de Bono M (2009) Coordinated regulation of foraging and metabolism in C. elegans by RFamide neuropeptide signaling. Cell Metab 9:375-385. CrossRef Medline

Conradt B, Horvitz HR (1998) The C. elegans protein EGL-1 is required for programmed cell death and interacts with the Bcl-2-like protein CED-9. Cell 93:519-529. CrossRef Medline

Das S, Sadanandappa MK, Dervan A, Larkin A, Lee JA, Sudhakaran IP, Priya R, Heidari R, Holohan EE, Pimentel A, Gandhi A, Ito K, Sanyal S, Wang JW, Rodrigues V, Ramaswami M (2011) Plasticity of local GABAergic interneurons drives olfactory habituation. Proc Natl Acad Sci U S A 108: E646-E654. CrossRef Medline

de Bruyne M, Clyne PJ, Carlson JR (1999) Odor coding in a model olfactory organ: the Drosophila maxillary palp. J Neurosci 19:4520-4532. Medline

Dusenbery DB (1978) Analysis of chemotaxis in the nematode Caenorhabditis elegans by countercurrent separation. J Exp Zool 188:41-47. Medline

Edwards JG, Michel WC (2002) Odor-stimulated glutamatergic neurotransmission in the zebrafish olfactory bulb. J Comp Neurol 454:294309. CrossRef Medline

Ennis M, Zimmer LA, Shipley MT (1996) Olfactory nerve stimulation activates rat mitral cells via NMDA and non-NMDA receptors in vitro. Neuroreport 7:989-992. CrossRef Medline

Ennis M, Zhu M, Heinbockel T, Hayar A (2006) Olfactory nerve-evoked, metabotropic glutamate receptor-mediated synaptic responses in rat olfactory bulb mitral cells. J Neurophys 95:2233-2241. Medline

Esposito G, Di Schiavi E, Bergamasco C, Bazzicalupo P (2007) Efficient and cell specific knock-down of gene function in targeted C. elegans neurons. Gene 395:170-176. CrossRef Medline

Ferkey DM, Hyde R, Haspel G, Dionne HM, Hess HA, Suzuki H, Schafer WR, Koelle MR, Hart AC (2007) C. elegans G protein regulator RGS-3 controls sensitivity to sensory stimuli. Neuron 53:39-52. CrossRef Medline

Fougeron AS, Farine JP, Flaven-Pouchon J, Everaerts C, Ferveur JF (2011) Fatty-acid preference changes during development in Drosophila melanogaster. PloS One 6:e26899. CrossRef Medline

Fox RM, Von Stetina SE, Barlow SJ, Shaffer C, Olszewski KL, Moore JH, Dupuy D, Vidal M, Miller DM 3rd (2005) A gene expression fingerprint of C. elegans embryonic motor neurons. BMC Genomics 6:42. CrossRef Medline

Gray JM, Hill JJ, Bargmann CI (2005) A circuit for navigation in Caenorhabditis elegans. Proc Natl Acad Sci U S A 9:3184-3191. Medline

Ha HI, Hendricks M, Shen Y, Gabel CV, Fang-Yen C, Qin Y, Colón-Ramos D, Shen K, Samuel AD, Zhang Y (2010) Functional organization of a neural network for aversive olfactory learning in Caenorhabditis elegans. Neuron 68:1173-1186. CrossRef Medline

Hadley JK, Halliwell JV (2010) Serotonin modulates glutamatergic transmission in the rat olfactory tubercle. Eur J Neurosci 31:659-672. CrossRef Medline

Hajdu-Cronin YM, Chen WJ, Patikoglou G, Koelle MR, Sternberg PW (1999) Antagonism between $\mathrm{G}_{\mathrm{o}} \alpha$ and $\mathrm{G}_{\mathrm{q}} \alpha$ in Caenorhabditis elegans: the RGS protein EAT-16 is necessary for $\mathrm{G}_{\mathrm{o}} \alpha$ signaling and regulates $\mathrm{G}_{\mathrm{q}} \alpha$ activity. Genes Dev 13:1780-1793. CrossRef Medline

Hallem EA, Sternberg PW (2008) Acute carbon dioxide avoidance in Caenorhabditis elegans. Proc Natl Acad Sci U S A 105:8038-8043. CrossRef Medline

Harris GP, Hapiak VM, Wragg RT, Miller SB, Hughes LJ, Hobson RJ, Steven R, Bamber B, Komuniecki RW (2009) Three distinct amine receptors operating at different levels within the locomotory circuit are each essential for the serotonergic modulation of chemosensation in Caenorhabditis elegans. J Neurosci 29:1446-1456. CrossRef Medline

Harris G, Mills H, Wragg R, Hapiak V, Castelletto M, Korchnak A, Komuniecki RW (2010) The monoaminergic modulation of sensory-mediated aversive responses in Caenorhabditis elegans requires glutamatergic/peptidergic cotransmission. J Neurosci 30:7889-7899. CrossRef Medline

Harris G, Korchnak A, Summers P, Hapiak V, Law WJ, Stein AM, Komuniecki P, Komuniecki R (2011) Dissecting the serotonergic food signal stimulating sensory-mediated aversive behavior in C. elegans. PLoS One 6:e21897. CrossRef Medline

Hart AC, Sims S, Kaplan JM (1995) Synaptic code from sensory modalities revealed by C. elegans GLR-1 glutamate receptor. Nature 378:82-85. CrossRef Medline

Hart AC, Kass J, Shapiro JE, Kaplan JM (1999) Distinct signaling pathways mediate touch and osmosensory responses in a polymodal sensory neuron. J Neurosci 19:1952-1958. Medline

Hellman AB, Shen K (2011) Sensory transduction channel subunits, tax-4 and tax-2, modify presynaptic molecular architecture in C. elegans. PLoS One 6:e24562. CrossRef Medline

Hills T, Brockie PJ, Maricq AV (2004) Dopamine and glutamate control area-restricted search behavior in Caenorhabditis elegans. J Neurosci 24: 1217-1225. CrossRef Medline

Horvitz HR, Chalfie M, Trent C, Sulston JE, Evans PD (1982) Serotonin and octopamine in the nematode C. elegans. Science 216:1012-1014. CrossRef Medline

Ignell R, Root CM, Birse RT, Wang JW, Nässel DR, Winther AM (2009) Presynaptic peptidergic modulation of olfactory receptor neurons in Drosophila. Proc Natl Acad Sci U S A 106:13070-13075. CrossRef Medline

Jacob TC, Kaplan JM (2003) The EGL-21 carboxypeptidase E facilitates acetylcholine release at Caenorhabditis elegans neuromuscular junctions. J Neurosci 23:2122-2130. Medline

Jansen G, Thijssen KL, Werner P, van der Horst M, Hazendonk E, Plasterk RH (1999) The complete family of genes encoding $G$ proteins of Caenorhabditis elegans. Nat Genet 21:414-419. CrossRef Medline

Juilfs DM, Fülle HJ, Zhao AZ, Houslay MD, Garbers DL, Beavo JA (1997) A subset of olfactory neurons that selectively express cGMP-stimulated phosphodiesterase (PDE2) and guanylyl cyclase-D define a unique olfac- 
tory signal transduction pathway. Proc Natl Acad Sci U S A 94:33883395. CrossRef Medline

Kass J, Jacob TC, Kim P, Kaplan JM (2001) The EGL-3 proprotein convertase regulates mechanosensory responses of Caenorhabditis elegans. J Neurosci 21:9265-9272. Medline

Kim K, Li C (2004) Expression and regulation of an FMRFamide-related neuropeptide gene family in Caenorhabditis elegans. J Comp Neurol 475: 540-550. CrossRef Medline

Komatsu H, Mori I, Rhee JS, Akaike N, Ohshima Y (1996) Mutations in a cyclic nucleotide-gated channel lead to abnormal thermosensation and chemosensation in C. elegans. Neuron 17:707-718. CrossRef Medline

Komatsu H, Jin YH, L’Etoile N, Mori I, Bargmann CI, Akaike N, Ohshima Y (1999) Functional reconstitution of a heteromeric cyclic nucleotidegated channel of Caenorhabditis elegans in cultured cells. Brain Res 821: 160-168. CrossRef Medline

Kuebler LS, Olsson SB, Weniger R, Hansson BS (2011) Neuronal processing of complex mixtures establishes a unique odor representation in the moth antennal lobe. Front Neural Circuits 5:7. CrossRef Medline

Lans H, Rademakers S, Jansen G (2004) A network of stimulatory and inhibitory G alpha-subunits regulates olfaction in Caenorhabditis elegans. Genetics 167:1677-1687. CrossRef Medline

Lee RY, Sawin ER, Chalfie M, Horvitz HR, Avery L (1999) EAT-4, a homolog of a mammalian sodium-dependent inorganic phosphate cotransporter, is necessary for glutamatergic neurotransmission in Caenorhabditis elegans. J Neurosci 19:159-167. Medline

Lesch BJ, Bargmann CI (2010) The homeodomain protein hmbx-1 maintains asymmetric gene expression in adult $C$. elegans olfactory neurons. Genes Dev 24:1802-1815. CrossRef Medline

L'Etoile ND, Bargmann CI (2000) Olfaction and odor discrimination are mediated by the C. elegans guanylyl cyclase ODR-1. Neuron 25:575-586. CrossRef Medline

Liu J, Ward A, Gao J, Dong Y, Nishio N, Inada H, Kang L, Yu Y, Ma D, Xu T, Mori I, Xie Z, Xu XZ (2010) C. elegans phototransduction requires a G protein-dependent cGMP pathway and a taste receptor homolog. Nat Neurosci 13:715-722. CrossRef Medline

Liu WW, Wilson RI (2013) Glutamate is an inhibitory neurotransmitter in the Drosophila olfactory system. Proc Natl Acad Sci U S A 110:1029410299. CrossRef Medline

Luo L, Gabel CV, Ha HI, Zhang Y, Samuel AD (2008) Olfactory behavior of swimming C. elegans analyzed by measuring motile responses to temporal variations of odorants. J Neurophysiol 99:2617-2625. CrossRef Medline

Mandairon N, Didier A, Linster C (2008) Odor enrichment increases interneurons responsiveness in spatially defined regions of the olfactory bulb correlated with perception. Neurobiol Learn Mem 90:178-184. CrossRef Medline

Martin JP, Hildebrand JG (2010) Innate recognition of pheromone and food odors in moths: a common mechanism in the antennal lobe? Front Behav Neurosci 4:pii:159. CrossRef Medline

Mellem JE, Brockie PJ, Zheng Y, Madsen DM, Maricq AV (2002) Decoding of polymodal sensory stimuli by postsynaptic glutamate receptors in $C$. elegans. Neuron 36:933-944. CrossRef Medline

Mello CC, Kramer JM, Stinchcomb D, Ambros V (1991) Efficient gene transfer in C. elegans: extrachromosomal maintenance and integration of transforming sequences. EMBO J 10:3959-3970. Medline

Mills H, Wragg R, Hapiak V, Castelletto M, Zahratka J, Harris G, Summers P, Korchnak A, Law W, Bamber B, Komuniecki R (2012) Monoamines and neuropeptides interact to inhibit aversive behaviour in Caenorhabditis elegans. EMBO J 31:667-678. CrossRef Medline

Milward K, Busch KE, Murphy RJ, de Bono M, Olofsson B (2011) Neuronal and molecular substrates for optimal foraging in Caenorhabditis elegans. Proc Natl Acad Sci U S A 108:20672-20677. CrossRef Medline

Miyabayashi T, Palfreyman MT, Sluder AE, Slack F, Sengupta P (1999) Expression and function of members of a divergent nuclear receptor family in Caenorhabditis elegans. Dev Biol 215:314-331. CrossRef Medline

Mousley A, Polese G, Marks NJ, Eisthen HL (2006) Terminal nerve-derived neuropeptide $\mathrm{Y}$ modulates physiological responses in the olfactory epithelium of hungry axolotls (Ambystoma mexicanum). J Neurosci 26: 7707-7717. CrossRef Medline

Mukhopadhyay S, Lu Y, Shaham S, Sengupta P (2008) Sensory signalingdependent remodeling of olfactory cilia architecture in C. elegans. Dev Cell 14:762-774. CrossRef Medline

Murakami M, Koga M, Ohshima Y (2001) DAF-7/TGF-beta expression re- quired for the normal larval development in C. elegans is controlled by a presumed guanylyl cyclase DAF-11. Mech Dev 109:27-35. CrossRef Medline

Nathoo AN, Moeller RA, Westlund BA, Hart AC (2001) Identification of neuropeptide-like protein gene families in Caenorhabditis elegans and other species. Proc Natl Acad Sci U S A 98:14000-14005. CrossRef Medline

Ohnishi N, Kuhara A, Nakamura F, Okochi Y, Mori I (2011) Bidirectional regulation of thermotaxis by glutamate transmissions in Caenorhabditis elegans. EMBO J 30:1376-1388. CrossRef Medline

Petzold GC, Hagiwara A, Murthy VN (2009) Serotonergic modulation of odor input to the mammalian olfactory bulb. Nat Neurosci 12:784-791. CrossRef Medline

Pierce-Shimomura JT, Morse TM, Lockery SR (1999) The fundamental role of pirouettes in Caenorhabditis elegans chemotaxis. J Neurosci 19:95579569. Medline

Pírez N, Wachowiak M (2008) In vivo modulation of sensory input to the olfactory bulb by tonic and activity-dependent presynaptic inhibition of receptor neurons. J Neurosci 28:6360-6371. CrossRef Medline

Pradel E, Zhang Y, Pujol N, Matsuyama T, Bargmann CI, Ewbank JJ (2007) Detection and avoidance of a natural product from the pathogenic bacterium Serratia marcescens by Caenorhabditis elegans. Proc Natl Acad Sci U S A 104:2295-2300. CrossRef Medline

Roayaie K, Crump JG, Sagasti A, Bargmann CI (1998) The G alpha protein ODR-3 mediates olfactory and nociceptive function and controls cilium morphogenesis in C. elegans olfactory neurons. Neuron 20:55-67. CrossRef Medline

Root CM, Masuyama K, Green DS, Enell LE, Nässel DR, Lee CH, Wang JW (2008) A presynaptic gain control mechanism fine-tunes olfactory behavior. Neuron 59:311-321. CrossRef Medline

Root CM, Ko KI, Jafari A, Wang JW (2011) Presynaptic facilitation by neuropeptide signaling mediates odor-driven food search. Cell 145:133-144. CrossRef Medline

Saveer AM, Kromann SH, Birgersson G, Bengtsson M, Lindblom T, Balkenius A, Hansson BS, Witzgall P, Becher PG, Ignell R (2012) Floral to green: mating switches moth olfactory coding and preference. Proc Biol Sci 279: 2314-2322. CrossRef Medline

Savigner A, Duchamp-Viret P, Grosmaitre X, Chaput M, Garcia S, Ma M, Palouzier-Paulignan B (2009) Modulation of spontaneous and odorantevoked activity of rat olfactory sensory neurons by two anorectic peptides, insulin and leptin. J Neurophysiol 101:2898-2906. CrossRef Medline

Schackwitz WS, Inoue T, Thomas JH (1996) Chemosensory neurons function in parallel to mediate a pheromone response in C. elegans. Neuron 17:719-728. CrossRef Medline

Tobin D, Madsen D, Kahn-Kirby A, Peckol E, Moulder G, Barstead R, Maricq A, Bargmann C (2002) Combinatorial expression of TRPV channel proteins defines their sensory functions and subcellular localization in $C$. elegans neurons. Neuron 35:307-318. CrossRef Medline

Torayama I, Ishihara T, Katsura I (2007) Caenorhabditis elegans integrates the signals of butanone and food to enhance chemotaxis to butanone. J Neurosci 27:741-750. CrossRef Medline

Troemel ER, Chou JH, Dwyer ND, Colbert HA, Bargmann CI (1995) Divergent seven transmembrane receptors are candidate chemosensory receptors in C. elegans. Cell 83:207-218. CrossRef Medline

Troemel ER, Kimmel BE, Bargmann CI (1997) Reprogramming chemotaxis responses: sensory neurons define olfactory preferences in C. elegans. Cell 91:161-169. CrossRef Medline

Tsunozaki M, Chalasani SH, Bargmann CI (2008) A behavioral switch: cGMP and PKC signaling in olfactory neurons reverses odor preference in C. elegans. Neuron 59:959-971. CrossRef Medline

Vogler C, Schild D (1999) Inhibitory and excitatory responses of olfactory receptor neurons of Xenopus laevis tadpoles to stimulation with amino acids. J Exp Biol 202: 997-1003. Medline

Vowels JJ, Thomas JH (1992) Genetic analysis of chemosensory control of dauer formation in Caenorhabditis elegans. Genetics 130:105-123. Medline

Wakabayashi T, Kitagawa I, Shingai R (2004) Neurons regulating the duration of forward locomotion in Caenorhabditis elegans. Neurosci Res 50: 103-111. CrossRef Medline

Ward S, Thomson N, White JG, Brenner S (1975) Electron microscopical reconstruction of the anterior sensory anatomy of the nematode Caenorhabditis elegans. J Comp Neurol 160:313-337. CrossRef Medline 
Winther AM, Acebes A, Ferrús A (2006) Tachykinin-related peptides modulate odor perception and locomotor activity in Drosophila. Mol Cell Neurosci 31:399-406. CrossRef Medline

Wragg RT, Hapiak V, Miller SB, Harris GP, Gray J, Komuniecki PR, Komuniecki RW (2007) Tyramine and octopamine independently inhibit serotoninstimulated aversive behaviors in Caenorhabditis elegans through two novel amine receptors. J Neurosci 27:13402-13412. CrossRef Medline

Wu Q, Zhao Z, Shen P (2005) Regulation of aversion to noxious food by Drosophila neuropeptide Y- and insulin-like systems. Nat Neurosci 8:1350-1355. CrossRef Medline

Yook K, Hodgkin J (2007) Mos1 mutagenesis reveals a diversity of mechanisms affecting response of Caenorhabditis elegans to the bacterial pathogen Microbacterium nematophilum. Genetics 175:681-697. CrossRef Medline
Yoshida K, Hirotsu T, Tagawa T, Oda S, Wakabayashi T, Iino Y, Ishihara T (2012) Odour concentration-dependent olfactory preference change in C. elegans. Nat Commun 3:739. CrossRef Medline

Yu S, Avery L, Baude E, Garbers DL (1997) Guanylyl cyclase expression in specific sensory neurons: a new family of chemosensory receptors. Proc Natl Acad Sci U S A 94:3384-3387. CrossRef Medline

Zheng Y, Brockie PJ, Mellem JE, Madsen DM, Maricq AV (1999) Neuronal control of locomotion in C. elegans is modified by a dominant mutation in the GLR-1 ionotropic glutamate receptor. Neuron 24:347-361. CrossRef Medline

Zwaal RR, Mendel JE, Sternberg PW, Plasterk RH (1997) Two neuronal G proteins are involved in chemosensation of the Caenorabditis elegans dauer-inducing pheromone. Genetics 145:715-727. Medline 